\title{
Kritická místa v matematice u českých žáků na základě výsledků šetření TIMSS $2007^{1}$
}

\author{
Miroslav Rendl a, Nad’a Vondrováb \\ a Univerzita Karlova v Praze, Pedagogická fakulta, Katedra psychologie \\ ${ }^{\mathrm{b}}$ Univerzita Karlova v Praze, Pedagogická fakulta, Katedra matematiky a didaktiky matematiky \\ Redakci zasláno 3. 5. 2013 / upravená verze obdržena 3. 9. 2013 / k uveřejnění \\ přijato 5. 9. 2013
}

\begin{abstract}
Abstrakt: Cílem empirické studie je popsat kritická místa matematiky základní školy, jak je lze vysledovat z výsledků našich žáků 8. ročníků v TIMSS 2007, a identifikovat pravděpodobné příčiny jejich obtížnosti. V první části je stručně uveden kontext výzkumu - mezinárodní srovnávací výzkumy v matematice a možnosti sekundární analýzy jejich dat. Ve druhé části podrobně popisujeme metodologii výzkumu. Analyzovali jsme data z tzv. almanachů TIMSS (výsledky našich žáků na úrovni konkrétních úloh a odpovědi učitelských dotazníků). K interpretaci možných příčin jsme používali také kurikulární dokumenty a analýzu zřejmě nejpoužívanější řady učebnic matematiky pro základní školy. Stanovili jsme kritérium, podle něhož je možné rozhodnout, zda je výkon našich žáků u dané úlohy pod jejich standardem, přičemž jsme vycházeli $\mathrm{z}$ porovnání jejich průměrné úspěšnosti s průměrnou úspěšností mezinárodního souboru. Tak byly identifikovány tzv. slabé a velmi slabé úlohy. Ty byly rozděleny do tří oblastí, které tedy můžeme považovat za místa, která jsou v matematice pro české žáky kritická: Algebra (s podoblastmi Funkce, Substituce, Rovnice a nerovnice, Výrazy), Posloupnosti, Obrazce a tělesa. U každé z těchto oblastí jsou prezentovány slabé a velmi slabé úlohy spolu s nástinem povahy obtíží, které při jejich řešení čeští žáci zřejmě měli, a jejich možných příčin. Ukazuje se, že je nutné získat ještě hlubší vhled do problematiky pomocí klinických rozhovorů přímo se žáky. To bude předmětem dalších článků.
\end{abstract}

Klíčová slova: TIMSS, matematické znalosti a dovednosti, algebra, posloupnosti, geometrie, obtíže v matematice

Ve výzkumu řešeném v rámci projektu GA ČR se zaměřujeme na otázku tzv. kritických míst matematiky základní školy, tedy těch oblastí, v nichž žáci často selhávají, jinak řečeno, která nezvládnou na takové úrovni, aby

1 Článek vznikl v rámci projektu GAČR P407/11/1740 Kritická místa matematiky na základní škole - analýza didaktických praktik učitelů.

DOI: $10.5817 /$ PedOr2014-1-22 
se jejich matematická gramotnost a její tvořivé užívání v každodenním životě produktivně vyvíjela. Tato kritická místa identifikujeme zejména prostřednictvím semistrukturovaných rozhovorů s učiteli matematiky, ovšem doplňkovým zdrojem jsou pro nás i výsledky našich žáků základní školy v matematice $\mathrm{v}$ mezinárodních srovnáních. Právě touto stránkou výzkumu se zabývá předložený článek, jehož cílem je identifikovat kritická místa matematiky druhého stupně základní školy na základě výsledků našich žáků v šetření TIMSS 2007 a popsat pravděpodobné prríčiny jejich obtížnosti.

Mezinárodní srovnávací výzkumy mají za cíl popsat stav a vývojové tendence školských systémů, jejich výkonnost, efektivitu a kvalitu i hledat vztahy mezi výsledky v těchto oblastech a dalšími proměnnými (Janík, 2013). Nejde však o pouhé sestavování mezinárodních žebříčkủ. Jak uvádí Janík (2013), tyto výzkumy představují

poměrně bohatý reservoár zahrnující data o výkonech a kompetencích žáků; o výukových postupech učitelů; o podmínkách, v nichž se žáci učí a učitelé vyučují; o jejich postojích ke vzdělávání a o názorech na ně; o kurikulárních akcentech $\mathrm{v}$ různých předmětech a $\mathrm{v}$ různých zemích a o mnohém dalším.

Mohou se tak stát důležitým zdrojem pro výzkum v oborových didaktikách. Podle Neubranda (2009, cit. podle Janík, 2013) lze z mezinárodních srovnávacích studií vyvozovat oborové i didaktické podněty pro výuku. To bude náplní tohoto článku.

\section{Mezinárodní srovnávací výzkumy v matematice}

Mezinárodní srovnávací výzkumy $\mathrm{v}$ matematice představují unikátní příležitost, jak sledovat u velkého vzorku žáků různé ukazatele, nejen jejich schopnost řešit vybrané úlohy v matematice, ale také jejich vztah k matematice, matematické sebevědomí či charakteristiky reálné výuky matematiky tak, jak je popisují sami učitelé. Mezinárodní i národní zprávy přinášejí zpravidla povšechné informace, které je nutné dále interpretovat. Napřs. se z nich můžeme dozvědět o poklesu úspěšnosti českých žáků osmých, resp. devátých ročníků v matematických testech šetření TIMSS i PISA (Tomášek, 2008; Straková, 2009), který dokumentuje tabulka 1. 
Tabulka 1

Vývoj výsledků TIMSS a PISA v čase

\begin{tabular}{lcccccc}
\hline & \multicolumn{2}{l}{$\begin{array}{l}\text { Celkové průměrné výsledky českých } \\
\text { žáků (populace 2) v TIMSS }\end{array}$} & \multicolumn{4}{l}{$\begin{array}{l}\text { Celkové výsledky českých } \\
\text { patnáctiletých žáků v matematických } \\
\text { testech PISA }\end{array}$} \\
\hline Rok & 1995 & 1999 & 2007 & 2003 & 2006 & 2009 \\
Celkový skór & 546 & 520 & 504 & 516 & 510 & 493 \\
\hline
\end{tabular}

Výsledky jsou vyjádřeny $\mathrm{v}$ tzv. Raschově skóru se střední hodnotou 500 a směrodatnou odchylkou 100 . Při těchto výsledcích by nešlo o poklesy nijak dramatické - zhruba čtyři desetiny směrodatné odchylky v intervalu 19952007 u TIMSS a dvě desetiny v intervalu 2003-2009 u PISA.

Ovšem výše prezentované výsledky TIMSS jsou ve skutečnosti zavádějící. V roce 1995 se šetření účastnili žáci sedmých a osmých ročníkủ a celkový výsledek našich žáků, jak ho uvádějí oficiální zprávy, je průměrem jejich výsledků. Dalších šetření se však účastnili pouze žáci osmých ročníků (a analogických ročníků víceletých gymnázií). Je evidentní, že za těchto podmínek je takové srovnání nekorektní. Vycházíme-li v roce 1995 pouze z výsledků žáků osmého ročníku, vypadá srovnání tak, jak je uvedeno v tabulce 2 .

Tabulka 2

Celkové průměrné výsledky českých žáků osmých ročníků v TIMSS

\begin{tabular}{lccc}
\hline Rok & 1995 & 1999 & 2007 \\
Celkový skór & 564 & 520 & 504 \\
Procentuální úspěšnost řešení úloh & 66 & $?$ & 49 \\
\hline
\end{tabular}

Pozn. Mezinárodní zpráva z r. 1999 bohužel neuvádí celkovou procentuální úspěšnost řešení úloh.

Znepokojivý trend se projevil i v šetření PISA. Zhoršení výkonu v matematických úlohách mezi roky 2003 a 2009 je v České republice největší ze všech 28 zemí, které se zúčastnily obou šetření (viz např. Palečková, Tomášek, \&

2 Od roku 1995 probíhají šetření TIMSS pravidelně ve čtyřletých cyklech, Česká republika se jich však neúčastnila vždy. Žáci 8. ročníků základní školy (a analogických ročníků víceletých gymnázií) se bohužel neúčastnili šetření v letech 2003 a 2011. (Čeští žáci 4. ročníků se účastnili šetření v letech 1995, 2007 a 2011.) 
Basl, 2010). Možnými příčinami poklesu v TIMSS i PISA se zabývá řada autorů i laická veřejnost (Basl, 2009; Grulichová, 2009; Hejný et al., 2010; Tomášek \& Mandíková, 2009/10) a rozhodně nejsou jednoznačné. Půjde spíše o souběh mnoha faktorů. Téměř všechny dostupné články se ovšem zabývají pouze celkovými výsledky a přinášejí povšechná sdělení. Z hlediska didaktiky matematiky jsou však důležitější než celkové výsledky informace týkající se konkrétních oblastí učiva, jimž je možno přičítat pokles ve výsledcích TIMSS a PISA. ${ }^{3}$ Protože položky výzkumu TIMSS více odpovídají matematickému kurikulu (Rabušicová, 2011), rozhodli jsme se k dalšímu zkoumání využít právě poslední výzkum TIMSS, který se zabýval matematikou v 8. ročníku a kterého se naši žáci zúčastnili, tedy TIMSS 2007.

Kromě národních a mezinárodních zpráv jsou data TIMSS, která jsou kdispozici na www.timss.org, zpracována ivsekundárních analýzách (bohužel spíše v zahraničí). Objevují se studie zabývající se rozdílem výkonnosti žáků podle genderu (např. Louis \& Mistele, 2012; Potužníková \& Straková, 2006). Další výzkumný směr se zabývá vlivem psychologických aspektů na výsledky TIMSS, např. př́stupu žáků $\mathrm{k}$ matematice, jejich sebevědomí v matematice apod. (např. Choi, Choi, \& McAninch, 2012). Zkoumán je také vliv socioekonomického prostředí testovaných žáků (např. Caponera \& Russo, 2010) či vliv kvalifikace jejich učitelů na úspěšnost v TIMSS (např. Dodeen et al., 2012) apod. Výsledkům sekundární analýzy TIMSS 1999 je věnována celá kniha (Robitaille \& Beaton, 2002).

V českém prostředí se však můžeme opřít jen o národní zprávu TIMSS 2007, případně publikace, které z této národní zprávy přímo vycházejí (Mandíková, 2009). Nejsou nám známy žádné publikace s výsledky sekundární analýzy dat TIMSS 2007, které by se zabývaly př́mo jednotlivými úlohami testu a jejich charakteristikami v souvislosti s úspěšností (českých) žákủ. ${ }^{4}$

\footnotetext{
0 identifikaci toho, které oblasti matematiky nejvíce přispěly $\mathrm{k}$ tomuto poklesu, jsme se pokoušeli více způsoby. Jedním z možných přístupů k problematice je porovnat $\mathrm{v}$ čase výsledky ve stejných oblastech učiva. To se však ukázalo jako obtížně proveditelné, protože v různých šetřeních byly testy členěny do různých obsahových domén. Např̀ v roce 1999 nebyly úlohy na úměrnost na rozdíl od roku 1995 vyčleněny zvlášt' a byly patrně zahrnuty do domény Zlomky a čísla. $V$ roce 2007 byly úlohy zařazované $v$ před chozím šetření do domény Měření zřejmě zahrnuty do Geometrie. Druhá možnost, jak zjistit, v čem se naši žáci zhoršili, spočívá v porovnání výsledků v jednotlivých opakovaně zadávaných úlohách. Ovšem v roce 2007 bylo z celkového počtu 214 úloh použito pouze 21 úloh z roku 1999 a žádná z roku 1995.

4 Pokud takové studie vznikly v zahraničí, zřejmě byly publikovány v lokálních časopisech. V nám dostupných mezinárodních databázích jsme podobný výzkum nenašli.
} 


\section{Metodologie - identifikace kritických míst}

Vnárodní zprávěTIMSSje uvedeno,žečeštížáci „byli nadprůměrnívaritmetice a v oblasti data a pravděpodobnost, průměrní při řešení geometrických úloh a podprůměrní v algebře" (Tomášek et al., 2008, s. 11). Ovšem takto obecně formulovaný závěr nemůže poskytnout dostatečné informace, které by se daly využít pro zlepšení výuky matematiky a tím i výsledků našich žáků. Je nutné se podívat př́mo na jednotlivé úlohy šetření, udělat jejich didaktickomatematický rozbor a hledat př́ćiny jejich obtížnosti. Položili jsme si tedy otázku: Jaká kritická místa matematiky základní školy lze vysledovat z výsledků našich žáků v TIMSS 2007 a jaké jsou pravděpodobné př́činy jejich obtížnosti?

TIMSS 2007 se celkově zúčastnilo 4845 českých žáků 8. ročníků základní školy a odpovídajících ročníků víceletých gymnázií. Žákům bylo zadáno celkem 214 úloh. ${ }^{5} \mathrm{Z}$ nich bylo sestaveno 14 testových sešitů, které zahrnovaly z poloviny úlohy z matematiky, druhou polovinu tvořily úlohy z prŕrodních věd. Na matematické úlohy měli žáci 45 minut. Každý žák tedy řešil nejčastěji 28-32 matematických úloh (jeden sešit obsahoval 33 a jeden 34 úloh), tedy zhruba jednu sedminu z celkového počtu úloh. Tomu odpovídá, že každou úlohu řešila jen část žáků - jejich počet se pohyboval v rozmezí od 676 do 701. To samozřejmě omezuje reprezentativnost vzorku pro každou jednotlivou úlohu. Přesto se domníváme, že počet žáků, který odpovídá velikosti 25-30 školních tříd, je vyšší, než jsou rozsahy vzorků běžně dostupné pro výzkumy v českém prostředí, a je pro naši analýzu dostatečný. Opatrnosti je třeba především tam, kde bychom se pokoušeli o srovnávání výsledků různých úloh, protože je mohly řešit různé soubory žáků a do rozdílných výsledků se nezbytně promítla i rozdílnost vzorků.

Úlohy TIMSS 2007 byly členěny podle dvou dimenzí. Z hlediska obsahu byly rozděleny do tzv. obsahových domén: Číslo (63 úloh), Algebra (64 úloh), Geometrie (47 úloh) a Data a pravděpodobnost (40 úloh). Dále člení TIMSS úlohy podle kognitivní dimenze, která má specifikovat „myšlenkové procesy, které žáci pravděpodobně používají, když se zabývají obsahem“ (Mullis et al., 2007, s. 117). Byly vyčleněny tři kognitivní domény - Prokazování znalostí (knowing, 81 úloh), Používání znalostí (applying, 88 úloh) a Uvažování (reasoning, 45 úloh). Prokazování znalosti

5 Technická zpráva TIMSS 2007 uvádí 215 úloh, ale úloha M02-15, která by patřila do tohoto počtu, není v almanachu výsledků uvedena. 
pokrývá fakta, procedury a pojmy (concepts), které žáci potřebují znát, [...] používání znalostí se zaměřuje na schopnost žáků řešit úlohy (problems) nebo odpovídat na otázky. Třetí doména, uvažování, jde za řešení rutinních úloh a zahrnuje neběžné situace, komplexní kontexty a vícekrokové úlohy. (Mullis et al., 2005, s. 33)

Jako příklady reprezentující kognitivní domény uvádíme následující úlohy.

Prokazování znalostí (úloha M10-07):

$\mathrm{x}+\mathrm{y}=12$ a $2 \mathrm{x}+5 \mathrm{y}=36$. Kolik jsou hodnoty $x$ a $y$ ?
A) $x=2, y=10$
B) $x=4, y=8$
C) $x=6, y=6$
D) $x=8, y=4$

Používání znalostí (úloha M10-08):

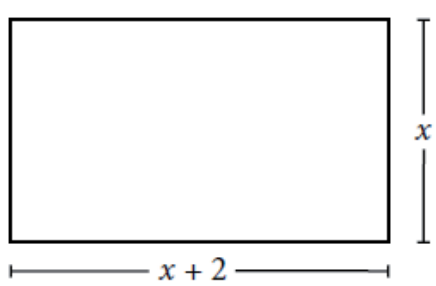

Který výraz vyjadřuje obsah tohoto obdélníku?
A) $x+2$
B) $x^{2}+2 x$
C) $2 x+2$
D) $4 x+4$

Obrázek 1. Zadání úlohy M10-08.

Uvažování (úloha M02-08):

Pepa ví, že pero stojí o 1 zed více než tužka. Jeho kamarád za 17 zedů koupil 2 pera a 3 tužky. Kolik zedů bude Pepa potřebovat, aby si mohl koupit 1 pero a 2 tužky? Napiš postup výpočtu.

V celém souboru úloh byly přibližně stejně zastoupeny úlohy s výběrem odpovědi (uzavřené) a s tvorbou odpovědi (otevřené). Prvních bylo 116, druhých 98. Otevřené úlohy byly kódovány jednotným systémem prostřednictvím proškolených osob. Ukázky kódovacího systému lze nalézt v publikaci (Tomášek et al., 2009). 
Data, která jsme analyzovali, zahrnují znění všech matematických úloh zadaných v TIMSS 2007 v češtině a dále jejich výsledky, jak je přinášejí tzv. almanachy dostupné na stránkách www.timss.org. Část těchto dat lze získat také na stránkách České školní inspekce. ${ }^{6}$

U uzavřených úloh, tedy úloh, kde mají žáci vybrat správnou odpověd' z nabízených možností, jsme měli k dispozici procentuální zastoupení výběru jednotlivých distraktorů a procento žáků, kteří úlohu vynechali. U otevřených úloh, tedy úloh s tvorbou odpovědi, jsme kromě procentuální úspěšnosti měli k dispozici kódy, jimiž výzkumníci kódovali např. částečně správné odpovědi či typy nesprávných odpovědí. Např́klad kódy pro úlohu M01-12, která je uvedená v oddíle 6, jsou: 10 (správná odpověd’ $18 \mathrm{~cm}^{2}$ ), 70 (nesprávná odpověd' $36 \mathrm{~cm}^{2}$ ), 79 (další nesprávná - včetně přeškrtnuté, vygumované nebo nečitelné odpovědi, značek nebo odpovědí nesouvisejících se zadáním), 99 (bez odpovědi).

U některých úloh je možné neúspěšnost našich žáků do značné míry vysvětlit tím, že podle zamýšleného i implementovaného kurikula se daná látka v 8. ročníku neprobírala. ${ }^{7}$ Zde se opíráme jednak o dokument Vzdělávací program Základní škola, který byl v době šetření TIMSS 2007 na základních školách zřejmě nejrozšířenějšši, ${ }^{8}$ o výsledky dotazníků, které vyplňovali učitelé testovaných žáků (v dalším textu učitelský dotazník), ${ }^{9}$ dále o dotazník, který vyplňovaly národní týmy a který se týkal zamýšleného kurikula, a konečně o analýzu obsahu řady učebnic matematiky pro 2. stupeň základní školy z nakladatelství Prometheus (autorského kolektivu vedeného 0. Odvárkem), která byla v době TIMSS 2007 zřejmě na školách nejrozšířenější.

Analýzu úloh jsme začali jejich zatříděním do určité oblasti školské matematiky. Brzy jsme dospěli k závěru, že ne vždy se s autory testu shodneme v jejich zařazení do té či oné domény. Zároveň je členění do čtyř domén TIMSS 2007 (Číslo, Algebra, Geometrie a Data a pravděpodobnost) příliš hrubé, než aby dokázalo postihnout, v čem reálně spočívají slabá místa našich

6 Viz http://www.csicr.cz/cz/O-nas/Mezinarodni-setreni-archiv/TIMSS/TIMSS-2007.

7 V národní zprávě TIMSS 2007 není tento fakt vůbec zmíněn. Bere se za zřejmé, že žáci látku, kterou testují úlohy TIMSS, probírali, a tedy je možné podle jejich úspěšnosti usuzovat na to, jakých dosáhli výsledků.

8 Bohužel není možné zjistit, podle jakého vzdělávacího programu byli testovaní žáci učeni, či jakou řadu učebnic používali.

9 Viz http://www.csicr.cz/getattachment/cz/O-nas/Mezinarodni-setreni-archiv/TIMSS/TIMSS -2007/ucitelsky-dotaznik-8r.pdf. 
žáků. Domény v TIMSS jsou sice dále členěny do tzv. tematických celků (topic areas), ovšem profily výkonů podle nich už Mezinárodní zpráva TIMSS nepodává (srov. Mullis et al., 2008). Navíc ani toto členění není z hlediska obsahu dostatečně homogenní. Např. v doméně Číslo je vyčleněn tematický celek Zlomky a desetinná čísla, který zahrnuje 23 úloh z celkového počtu $63 \mathrm{v}$ celé doméně. $V$ šesti př́padech z těchto 23 úloh se výsledky českých žáků pohybují pouze kolem mezinárodního průměru. Ve zbylých 40 úlohách domény Číslo najdeme pouze pět úloh s takto slabými výsledky. Bylo by tedy možno usoudit, že pro naše žáky je problematická oblast zlomků a desetinných čísel. Ve skutečnosti se ovšem všech oněch šest úloh se slabými výsledky týká pouze zlomků, nikoli desetinných čísel. Z těchto důvodů jsme vypracovali vlastní kategorizaci úloh, kterou uvádíme v tabulce 3.

Dále bylo nutno rozhodnout, které úlohy budeme považovat za představitele problematických oblastí. Nejde jednoduše o všechny úlohy, v nichž naši žáci dosáhli špatných výsledků. Mohlo by se jednat o obtížné úlohy, v nichž byli málo úspěšní i žáci v ostatních zemích. Proto jsme vyšli z porovnání průměrné úspěšnosti našich žákư ${ }^{10} \mathrm{~s}$ průměrnou úspěšností mezinárodního souboru. Průměrná odchylka úspěšnosti našich žáků od úspěšnosti mezinárodního souboru činí $+9,4 \%$. ${ }^{11}$ Tuto hodnotu jsme tedy vzali jako standard českých žáků. Následně jsme porovnali výkon českých žáků u jednotlivých úloh s jejich standardem. Za jejich slabiny pak považujeme úlohy, v nichž se jejich výsledky odlišují od mezinárodního souboru o méně než $5 \%$. V intervalu 0 až + $5 \%$ označujeme úlohy jako slabé, při záporné odchylce pak jako velmi slabé. Tato konstrukce standardu a odchylek od něj má tu výhodu, že je nezávislá na samotné úspěšnosti $\mathrm{v}$ úloze, která se pochopitelně mění v závislosti na obtížnosti úlohy.

Tabulka 3 podává ve sloupcích přehled jednotlivých námi vyčleněných oblastí a údajů o výsled cích našich žáků. Kategorie nejsou striktně disjunktní, zejména úlohy z oblasti Slovní úlohy jsou vesměs kódovány i v jiných oblastech. To je dáno tím, že některé úlohy zřetelně nesou dva aspekty, z nichž každý může tvořit jádro obtížnosti, které se snažíme postihnout. Je ovšem třeba upozornit, že data TIMSS zdaleka ne vždy dovolují identifikovat, který

10 Úspěšnost je dána jako procento žáků, kteří danou úlohu řešili správně. (Pro tentýž indikátor se často užívá také termín obtížnost - difficulty). V našem textu ji někdy označujeme také jako výkon žáků.

11 Pokud vyřadíme úlohy, které dále označujeme za slabé a velmi slabé, zvýší se průměrný odstup od mezinárodního průměru na $+13,6 \%$. 
z těchto aspektů je pro naše žáky obtížnější. I když u úloh s výběrem odpovědi máme k dispozici údaje o frekvenci jednotlivých chybných odpovědí, často nelze postupy, které za nimi stojí, interpretovat jednoznačně. Tím spíše to platí o otevřených úlohách, kde máme většinou údaj o počtu správných řešení, nikoli však o typech chyb, jichž se žáci dopouštěli v odpovědích, které byly kódovány jako nesprávné.

Tabulka 3

Přehled slabých a velmi slabých úloh v TIMSS 2007

\begin{tabular}{|c|c|c|c|c|c|c|c|}
\hline & $\begin{array}{c}\text { Celkový } \\
\text { počet } \\
\text { úloh }\end{array}$ & $\begin{array}{c}\text { Počet } \\
\text { slabých } \\
\text { úloh }\end{array}$ & $\begin{array}{l}\text { Počet } \\
\text { velmi } \\
\text { slabých } \\
\text { úloh }\end{array}$ & $\begin{array}{c}\text { Procento } \\
\text { slabých } \\
\text { a velmi } \\
\text { slabých } \\
\text { úloh }\end{array}$ & $\begin{array}{l}\text { Procento } \\
\text { velmi } \\
\text { slabých } \\
\text { úloh }\end{array}$ & $\begin{array}{c}\text { Průměrná } \\
\text { úspěšnost } \\
\text { českých } \\
\text { žáků } \\
\text { v dané } \\
\text { oblasti }\end{array}$ & $\begin{array}{c}\text { Průměrný } \\
\text { rozdíl českého } \\
\text { a mezinárodního } \\
\text { souboru }\end{array}$ \\
\hline Algebra & 45 & 8 & 16 & $53 \%$ & $36 \%$ & 43,1 & 4,7 \\
\hline Funkce & 6 & 0 & 3 & $50 \%$ & $50 \%$ & 34,5 & 1,9 \\
\hline Substituce & 12 & 3 & 6 & $75 \%$ & $50 \%$ & 35,5 & 2,0 \\
\hline $\begin{array}{l}\text { Rovnice, } \\
\text { nerovnice }\end{array}$ & 10 & 2 & 4 & $60 \%$ & $40 \%$ & 37,4 & 2,8 \\
\hline Výrazy & 17 & 3 & 3 & $35 \%$ & $18 \%$ & 55,0 & 8,6 \\
\hline Posloupnosti & 17 & 4 & 3 & $41 \%$ & $18 \%$ & 35,7 & 6,3 \\
\hline Obrazce, tělesa & 20 & 6 & 5 & $55 \%$ & $24 \%$ & 38,7 & 5,4 \\
\hline $\begin{array}{l}\text { Geometrie (bez } \\
\text { obrazců a těles) }\end{array}$ & 30 & 6 & 3 & $30 \%$ & $10 \%$ & 53,4 & 11,1 \\
\hline Č́sla & 44 & 5 & 6 & $25 \%^{10}$ & $14 \%$ & 54,4 & 11,2 \\
\hline Úměra, poměr & 11 & 2 & 1 & $27 \%$ & $9 \%$ & 57,7 & 10,6 \\
\hline Procenta & 9 & 0 & 0 & $0 \%$ & $0 \%$ & 61,2 & 13,5 \\
\hline Slovní úlohy & 36 & 5 & 1 & $17 \%$ & $3 \%$ & 50,5 & 13,9 \\
\hline Pravděpodobnost & 8 & 2 & 1 & $38 \%$ & $13 \%$ & 57,8 & 11,3 \\
\hline $\begin{array}{l}\text { Souřadnice, } \\
\text { grafy v soustavě } \\
\text { souřadnic }\end{array}$ & 6 & 0 & 2 & $33 \%$ & $33 \%$ & 50,9 & 4,3 \\
\hline Statistika & 6 & 0 & 2 & $33 \%$ & $33 \%$ & 33,6 & 3,6 \\
\hline Reprezentace dat & 27 & 0 & 1 & $4 \%$ & $4 \%$ & 56,3 & 14,4 \\
\hline
\end{tabular}

$\overline{12} \mathrm{Z}$ těchto 11 úloh se 6 týká zlomků. 
Z tabulky 3 je patrné, že k celkově slabším oblastem českých žáků patří Algebra, Posloupnosti ${ }^{13}$ a Obrazce a tělesa ${ }^{14}$, naopak Čísla patří spíše k jejich silnějším stránkám.

Z hlediska kognitivních domén je z našich analýz patrné, že nejmenší počet námi vymezených slabých a velmi slabých úloh se vyskytoval $\mathrm{v}$ doméně Prokazování znalostí (26\%). Naopak nejvyšší počet slabých úloh je v doméně Používání znalostí - 48 \%, v doméně Uvažování je to $42 \%$. (Zajímavé je, že při přepočtu na Raschův skór, kde při metodě IRT dochází k rozsáhlým interpolacím, jsou skóry ve všech doménách zhruba stejné - Znalosti: 502, Aplikace: 504, Uvažování: 500.)

Je možno si povšimnout i dalších souvislostí. Občas se mluví o tom, že čeští žáci dobře zvládají typicky školní úlohy a prokazují typicky školní znalosti, ale neumějí je aplikovat. Podíváme-li se z tohoto hlediska na úspěšnost řešení slovních úloh, dojdeme k zajímavým závěrům.

Za slovní úlohu zde považujeme úlohy s (pseudo)reálným kontextem (nejde tedy o jakoukoli úlohu zadanou slovy). Ve 36 takto identifikovaných slovních úlohách byla průměrná úspěšnost českých žáků o $14 \%$ vyšší, než byl mezinárodní průměr. Naopak mnohem bliže k hodnotám mezinárodního průměru klesali naši žáci v řadě oblastí, v nichž šlo spíše o zacházení s typicky matematickým aparátem, jazykem a symbolikou.

Je možno provést ještě jiné srovnání, které vede k témuž závěru. Převažující kognitivní doménou reprezentovanou ve slovních úlohách bylo Používání znalostí. Bylo mu věnováno 23 ze 36 úloh. ${ }^{15} \mathrm{~V}$ těchto 23 úlohách je průměrná úspěšnost našich žáků o $13 \%$ vyšší než u mezinárodního souboru. Oproti tomu v ostatních, „ne-slovních“ úlohách této kognitivní domény je průměrná úspěšnost našich žáků oproti mezinárodnímu souboru vyšší jen o 7 \%.

Tato zjištění jsou v rozporu s často uváděným názorem, že selhávání našich žáků v matematice je způsobeno nižší úrovní čtenářské gramotnosti. Také teze o tom, že do výuky matematiky je třeba zavést mnohem více úlohy s praktickým kontextem, blízké reálnému životu, není těmito výsledky pod-

13 Úlohy, které jsme vyčlenili do oblasti Posloupnosti, řadí TIMSS vesměs do domény Algebra.

14 Tuto oblast jsme vyčlenili z domény TIMSS Geometrie, naše oblast Geometrie pak zahrnuje zbytek úloh původní domény. Z tabulky 3 je patrné, nakolik mají naši žáci v těchto dvou částech původní domény rozdílnou úspěšnost.

158 úloh pak bylo na Uvažování a pouze 5 na Prokazování znalostí. 
pořena. Její uplatnění by vedlo paradoxně $\mathrm{k}$ tomu, že budeme naše žáky více učit to, co jim jde, a méně to, co je jejich slabinou.

Kromě celkového porovnání jednotlivých oblastí se pokusíme o podrobnější pohled na podoblasti a typy úloh. Omezíme se přitom na oblasti, které jsme identifikovali jako slabé. Pro zajímavost uvedeme někdy i ty úlohy, v nichž byly výsledky našich žáků naopak vysoko nad mezinárodním průměrem. Přesné zadání části úloh z bloků označených M01-M05 a M07 ${ }^{16}$ lze dohledat v publikaci ÚIV (Tomášek et al., 2009). Další část úloh, které byly uvolněny až v roce 2013, je možno najít na stránkách www.timss.org pod odkazem na šetření TIMSS $2011 .{ }^{17}$ Neuvolněné úlohy popíšeme tak, aby bylo jasné, o co v nich jde. Jejich přesné zadání uvést pochopitelně nelze.

\section{Algebra jako kritické místo}

Nejhorších výsledků - ve srovnání s mezinárodním průměrem - dosáhli čeští žáci v úlohách zaměřených na funkce a/nebo vyžadujících substituci. Je ovšem patrné, že hranice mezi dílčími oblastmi Algebry jsou neostré a mnohé úlohy by bylo možné zařadit i do jiné dílčí oblasti.

\subsection{Funkce}

Tato oblast obsahuje pouze šest úloh a v polovině z nich jsou výsledky našich žáků nad mezinárodním průměrem. V úloze M04-05B je třeba vypočítat čas při dráze $40 \mathrm{~km}$ a rychlosti $30 \mathrm{~km} / \mathrm{h}$ (úspěšnost 22,5 \%, což je ovšem o $9,2 \%$ nad mezinárodním průměrem $)^{18}$, $\mathrm{v}$ úloze M04-05C je třeba vypočítat čas při dráze $15 \mathrm{~km}$ a rychlosti 7,5 km/h (úspěšnost 39,2\%; + 17,6\%). Z toho je pěkně vidět, jak výrazně kolísá úspěšnost jen při změně zadaných čísel. Jde o úlohy otevřené.

${ }_{16}$ Jde o počáteční tř̌i znaky ve značení úlohy, další dvojčíslí za pomlčkou značí pořadí úlohy v bloku.

Úlohy s kódy začínajícími M08, M12 a M14 nebyly dosud uvolněny, nelze je tedy vyhledat ve veřejně dostupných zdrojích. My jsme k nim (v českém znění) získali př́istup jen pro účely výzkumu.

17 Jde o úlohy pěti bloků, jejichž značení z r. 2011 ovšem neodpovídá tomu, které bylo použito v TIMSS 2007. Bloky byly přeznačeny takto (první údaj je námi použité značení z roku 2007, druhý údaj udává nové značení z roku 2011): M06 -> M03, M09 -> M05, M10 -> M06, M11 -> M07, M13 -> M01. Úlohy jsou pochopitelně v anglickém znění.

18 Nadále budeme v závorce za označením nebo popisem úlohy uvádět nejprve úspěšnost našich žáků v procentech, za středníkem pak odchylku od úspěšnosti mezinárodního souboru. 
Poněkud nižší úspěšnost vzhledem $\mathrm{k}$ mezinárodnímu průměru vidíme v neuvolněné uzavřené úloze M12-05, v níž je puntíky vyznačeno 5 bodů v soustavě souřadnic (jeden z nich je na ose $x$ a jeden na ose $y$ ) a má se zjistit, která ze čtyř variant předpisu lineární funkce vyjadřuje vztah mezi těmito body. (Úspěšnost je 58 \%; + 5,4\%.)

\section{Slabé a velmi slabé úlohy}

Ve srovnání s mezinárodním souborem jsou naši žáci nejméně úspěšní v (neuvolněné) uzavřené úloze M12-06 (úspěšnost 28,2 \%; -8 \%), v níž je dána konkrétním číslem průměrná rychlost auta a žák má vybrat vzorec, podle kterého se vypočítá vzdálenost, kterou auto ujede za dobu $t$. Vzdálenost je označena jako $d$.

Při srovnání s výše zmíněnými úlohami M04-05B a C, které jsou také „úlohami o pohybu“, jde o výsledek diametrálně odlišný. Na první pohled to vypadá, že čeští žáci řeší jejich konkrétní zadání z hlediska mezinárodního srovnání nadprůměrně; jakmile však jde o algebraické vyjádření vztahu a nikoli o konkrétní číselné zadání, situace se mění. Tento dojem je zesílen zvláštními výsledky mezinárodního souboru - že totiž v mezinárodním průměru řeší žáci úlohu M12-06, tedy volbu algebraického vyjádření, v průměru úspěšněji než výpočty při konkrétních číselných zadáních.

Pro anglicky mluvící země je však záhada možná do určité míry vysvětlitelná tím, že v angličtině se dráha značí $d$ (distance) a správná rovnice v úloze M12-06 odpovídá anglické podobě klasického vzorce: $d=v \cdot t$. V tom případě jsou naši žáci znevýhodněni, protože v úloze řeší navíc substituci (náhradu proměnné $d$ proměnnou $s$ ).

Ve zbylých dvou úlohách oblasti Funkce dosáhli naši žáci také horšího výsledku, než je mezinárodní průměr. Uzavřená úloha M04-08 (úspěšnost 24,5 \%; - 5,5 \%) má toto znění: Který bod leží na prrímce $y=x+2$ ? (Varianty odpovědí jsou uvedeny spolu $s$ procentem našich žáků, kteří je vybrali. Celkem 22,2 \% žáků úlohu vynechalo.)
A: $[0,-2] 25,7 \%$,
B: $[2,-4] 19,9 \%$,
C: $[4,6] 24,5 \%$,
D: $[6,4] 7,7 \%$;

Domníváme se, že problémem může být, že u této úlohy nebylo explicitně napsáno $x=0, y=-2$, ale byla zadána uspořádaná dvojice. Hlavním zdrojem chyb byla záměna pořadí hodnot $\mathrm{v}$ uspořádané dvojici. Tomu by odpovídaly nesprávné odpovědi A a D. Přispívá k tomu i to, že v rovnici, do níž žáci 
dosazovali, bylo nejdříve písmeno $y$ a pak teprve $x$ a někteří žáci tedy „logicky“ dosazovali čísla z uspořádaných dvojic zleva. Ve variantě B se k tomu mohla přidružit chyba ve znaménku, tedy problém se zápornými čísly. Je tedy patrné, že obtížným momentem úlohy není primárně dosazení čísel, ale koncept uspořádané dvojice. Na druhou stranu nabízené varianty ani jinou možnost chyby nenabízejí

V úloze M05-10 (úspěšnost 38,4 \%; -6 \%) je dána tabulka, kde v prvním řádku je několik hodnot proměnné $x$ a ve druhém řádku jsou k nim příslušné hodnoty proměnné $y$ :

$$
x: 1,2,3,4,5
$$

$y: 1,3,5,7,9$

Otázka zní, která ze čtyř daných rovnic vyjadřuje vztah proměnných $x$ a $y$. Správná odpověd' je $y=2 x-1$.

Všechny tři chybné varianty odpovědi (distraktory) nabízejí rovnice, které vyhovují pouze jedné dvojici proměnných $x, y$. Žáci volili odpověd' nejčastěji podle druhé dvojice ( $25 \%$ žáků), dále pak podle první a poslední dvojice (13\%, resp. $11 \%$ ).

Ani problém úlohy M05-10 není v samotném dosazení - každá chybná varianta indikuje dosazení některé $\mathrm{z}$ dvojic. (Na druhou stranu ovšem varianta, které by nevyhovovala žádná z dvojic, nebyla autory úlohy nabídnuta.) Problém je v tom, že žáci netestují všechny dvojice. To svědčí spiše pro nepochopení povahy funkce a toho, jak ji rovnice vyjadřuje, resp. pro problémy s přechodem mezi různými reprezentacemi funkcí (v tomto př́ípadě rovnicí a tabulkou). Dalším možným faktorem neúspěchu mohl být i fakt, že pojem rovnice je v 8. ročníku (a na základní škole vůbec) spojen s hledáním jednoho řešení - jeho nalezením úloha končí.

Určité vysvětlení neúspěchu našich žáků u výše uvedených úloh najdeme v učitelských dotaznících. Podle nich se se zjištováním „hodnot funkcí/ vzorců pro dané hodnoty proměnných" setkalo jen $48 \%$ testovaných žáků a s „ekvivalentními vyjádřeními funkcí - uspořádané dvojice, tabulka, graf, rovnice nebo slovní vyjádření" jen 19\% (Mullis et al., 2008). To potvrzuje i Vzdělávací program Základní škola, v němž jsou funkce plánovány až na 9. ročník. 


\subsection{Substituce (dosazování)}

Úlohy vyžadující substituci (náhradu proměnné čísly, jinou proměnnou nebo výrazy) nejsou v rámci TIMSS zvlášt' vyznačeny, ovšem při našich analýzách jsme si všimli, že u relativně velkého počtu úloh, v nichž naši žáci nebyli úspěšní, šlo právě o dosazení čísel nebo proměnných.

Z celkového počtu 12 úloh dosáhli naši žáci svého standardu $(9,4 \%$ nad mezinárodním průměrem) nebo výsledků jen mírně horších ve třech úlohách vyžadujících dosazení konkrétních kladných číselných hodnot za jednu či dvě proměnné do výrazu (M06-06, M09-06, M12-07). Vždy byla konkrétně zadána hodnota proměnné, která se měla dosazovat, např. $t=9$.

\section{Slabé a velmi slabé úlohy}

Slabých výsledků dosáhli naši žáci u dvou úloh, kde podstatou řešení byla víceméně intuitivní identifikace násobku výrazu, např v úloze M06-08 (úspěšnost $32,4 \% ;+4,8 \%$ ): $a+b=25$, kolik je $2 a+2 b+4$. Podobně je tomu v neuvolněné úloze M14-03 (66,4 \%, +4,8 \%).

Na hodnoty úspěšnosti kolem mezinárodního průměru klesají výsledky našich žáků v úlohách, kdy mají do rovnice, resp. do výrazu dosadit dvojice hodnot, aby ověrili platnost rovnosti.

Úlohou toho typu je neuvolněná úloha M08-08 (úspěšnost 36,2 \%; -1,2 \%), kde se má zjistit, která ze čtyř nabízených rovnic má jako řešení danou dvojici čísel. Např. by mohla být zadána dvojice $x=3$ a $y=8$ a nabídnuty čtyři rovnice, z nichž jediná je po dosazení hodnot platná. Nejpochopitelnější chybou je záměna $x$ a $y$ při dosazování $(13,2 \%$ žáků): $3 x-8 y=0$. Avšak nejčastější špatná odpověd' $(25,4 \%)$ odpovídá tomu, kdy by jako správné řešení byla vybrána rovnice $8 x+3 y=24$. Zdá se, že žáci nejdř́íve dosazují zvlášte číslo $x$, pak zvlášt' číslo $y$ a druhý sčítanec ignorují (jakoby ověřovali vždy jen jednu proměnnou), a dostanou tedy v obou případech číslo 24 .

Podobná úloze M08-08 je neuvolněná úloha M14-07 (52,8 \%; -1,2\%), kde mají žáci naopak hledat řešení $\mathrm{k}$ zadané rovnici - tedy je zadána rovnice o dvou neznámých a čtyři uspořádané dvojice přirozených čísel a žáci mají zjistit, která dvojice čísel je řešením rovnice. Úspěšnost je vyšší než u M08-08, což je zřejmě dáno různou obtížností zadání - je těžší přiřadit jednu ze čtyř složitějších vztahových struktur (rovnic) zadaným číslům než najít čísla pro jedinou zadanou strukturu. Všechny tři varianty chybných 
odpovědí lze interpretovat jako záměnu hodnot x $a$ y $\mathrm{v}$ uspořádané dvojici. Dospíváme tak ke stejnému závěru jako výše u úlohy M04-08, že tu totiž problém nespočívá primárně v substituci, ale v konceptu uspořádané dvojice. Zároveň je možno si všimnout, jak se v těchto strukturálně téměř shodných úlohách liší jednak úspěšnost, jednak míra vynechání úlohy (zde pouze 8,8 \% oproti $22,2 \%$ v M04-08). Opět se tu zřejmě potvrzuje, že žákům v úloze M04-08 dělalo problémy, resp. odrazovalo je od pokusu o řešení, že museli při dosazování pracovat se zápornými čísly.

V uzavřené úloze M04-03 mají žáci do daného výrazu dosadit hodnoty proměnných $a$ a $b$ (úspěšnost 33,8 \%; $-0,4 \%$ ). Nejčastější špatná odpověd' (téměř $45 \%$ ) odpovídá tomu, že žáci nesprávně dosazují do výrazu $-b$ hodnotu $b=-1$ a dostávají číslo -1 místo 1 .

O dosazování šlo i v uzavřené úloze M06-10 (úspěšnost 25,0 \%; +0,2%):

$$
(0,-1),(1,3)
$$

Kterou z rovnic splňují OBĚ dvojice čísel $(x, y)$ ?

$$
\text { a) } x+y=-1 \text {, b) } 2 x+y=5 \text {, c) } 3 x-y=0 \text {, d) } 4 x-y=1
$$

Kromě dvou obtížných momentů, které jsme viděli již výše (žáci dosazují jen jednu z uspořádaných dvojic a jedna z dvojic obsahuje záporné číslo), je tentokrát situace ztížena ještě tím, že rovnice musí být splněna současně pro obě dvojice čísel. Čekali bychom tedy, že úloha bude mít ještě nižší úspěšnost než M04-08. Ve skutečnosti je ovšem úspěšnost téměř shodná, téměř shodný je také počet žáků, kteří tuto úlohu úplně vynechali (21\%). Podívámeli se ovšem na zadání a výsledky blíže, je patrné, že $\mathrm{k}$ záměně pořadí v uspořádaných dvojicích vlastně nemohlo dojít, protože žádná z variant odpovědí takovou možnost nenabízí. Všechny chybné odpovědi pak spočívají ve výběru rovnice, která vyhovuje pouze jedné dvojici čísel. Na druhou stranu si ovšem u správné odpovědi nemůžeme být jisti, že řešitelé nepoužili tutéž chybnou strategii. Ta by pak vedla k úspěchu víceméně náhodně.

Dodejme, že čeští žáci se s velkou pravděpodobností setkali s pojmem rovnice jen u lineární rovnice $s$ jednou proměnnou, ne se dvěma proměnnými. Lineární funkce se v programu Základní škola objevují až v 9. ročníku.

Nejmenší úspěšnost byla u neuvolněné úlohy M14-10 (úspěšnost 12,5 \%; $-0,8 \%$ ), kde byl rovnicí dán vztah mezi třemi proměnnými, přičemž se v rov- 
nici objevil lomený výraz ve formě „desetinné číslo lomeno 1000 “. K řešení stačilo dosadit hodnoty dvou proměnných, které byly ovšem uvedeny v poměrně komplikovaném slovním zadání. Na druhou stranu nebylo potřeba provádět žádné ekvivalentní úpravy rovnice. Žáci se zřejmě textu nebo komplikovaného výrazu ${ }^{19}$ zalekli, protože téměř $50 \%$ se jich o výpočet vůbec nepokusilo.

Výrazněji pod mezinárodním průměrem jsou výsledky českých žáků ve dvou neuvolněných úlohách, kde je třeba do algebraického výrazu dosadit za každou z dvojice proměnných algebraický výraz složený z čísla a proměnné (M08-11A - úspěšnost 30,7 \%; -2,7 \%, M08-11B, úspěšnost 8,8 \%; -4 \%). Obě úlohy jsou otevřené, takže bohužel nevíme nic o povaze chyb, kterých se žáci dopouštěli. $V$ obou př́padech úlohu významné procento žáků vynechalo (17\%, resp. $20 \%$ ).

Dodejme, že výrazy a dosazování do výrazů ${ }^{20}$ bylo v programu Základní škola plánováno na 8. ročník. Podle učitelského dotazníku se s „dosazováním daných čísel do výrazů a výpočtem hodnoty“ setkalo $99 \%$ testovaných žáků (o dosazování výrazů s proměnnou se v dotazníku nemluví). $V$ analyzované řadě učebnic žádné úlohy, v nichž se do výrazu má dosadit jiný výraz, který obsahuje proměnnou, nejsou.

\subsection{Rovnice a nerovnice}

Další oblastí, ve které se objevuje velká část úloh s výsledky pod standardem českých žáků, jsou Rovnice a nerovnice. (Místy je ovšem obtížné rozhodnout, zda daná úloha nespadá spíše do oblasti Výrazy.)

Významněji nad mezinárodním průměrem jsou výsledky u tří úloh. U první $\mathrm{z}$ nich jde o řešení klasické rovnice s jednou neznámou, $\mathrm{v}$ níž se ekvivalentní úprava (přičítání) netýká neznámé, ale čísla (uzavřená úloha M07-05, úspěšnost $69,1 \% ;+11,5 \%$ ). Další úloha vyžaduje sestavení rovnice pro „,součet délek stran trojúhelníku“, které jsou zadány jako jednoduché aditivní výrazy s toutéž proměnnou (M08-10A - úspěšnost 36,5 \%; +12,7 \%). Třetí, uzavřená, úloha je řešitelná úvahou, tedy i bez sestavení rovnice (M11-12, úspěšnost $52,1 \%$; +8,8 \%).

19 Pro ně zřejmě neznámého - podle programu Základní škola se lomené výrazy měly probírat až v 9. ročníku.

20 Ovšem není specifikováno, zda se jedná též o dosazení výrazů s proměnnými, nejen čísel. 


\section{Slabé a velmi slabé úlohy}

Slabé úlohy v této oblasti jsou dvě. M04-06 je uzavřená slovní úloha, v níž je dána rovnice výpočtu poplatku za zásilku $(y=4 x+30$, kde $x$ je hmotnost v gramech, $y$ je cena $\mathrm{v}$ zedech), a hledá se nejvyšší hmotnost zásilky, kterou je možno poslat za 150 zedů (úspěšnost 38,8 \%; +4,9\%). Nejčastější špatná odpověd' $(22,8 \%)$ odpovídá tomu, že žáci správně dosadí $y=150$, odečtou od obou stran rovnice 30 , ale už neudělají druhou úpravu, tj. dělení obou stran rovnice číslem 4 . Tedy mají problém s řešením lineární rovnice o dvou krocích.

Zatímco u předchozí úlohy můžeme za slabý výsledek vinit i poměrně netradiční formulaci úlohy (nejvyšší hmotnost zásilky), u neuvolněné úlohy M08-06 (úspěšnost 50,8 \%; +4,1\%) se jedná o klasickou lineární rovnici. U rovnice typu $7 x=11$ volilo celkem $22,5 \%$ žáků chybnou odpověd' typu 7/11 (nesprávný pokus o ekvivalentní úpravu - vydělení rovnice číslem 7), 18,5 \% variantu odpovídající řešení 77 (nesprávná ekvivalentní úprava).

Typické pro české žáky jsou horší výsledky při úpravách lineární nerovnice. U uzavřené úlohy M01-04: $x / 3>8$ (úspěšnost 29,4 \%; -2 \%) nejčastěji vybírali žáci odpověd' $x>8 / 3$, což by podobně jako u rovnic odpovídalo nesprávné ekvivalentní úpravě. Složitější nerovnici M06-07: $9 x-6<4 x+4$ úspěšně vyřešilo jen $11,5 \%(-5,8 \%)$ a $31,2 \%$ žáků ji vynechalo.

Za svým standardem (a dokonce i za mezinárodním průměrem) čeští žáci výrazně zaostávají také v řešení soustavy dvou lineárních rovnic (M10-07 - úspěšnost 40,1 \%; -5 \%). Tuto úlohu s volbou odpovědi bylo možno řešit také postupným testováním nabídnutých kladných celočíselných variant hodnot neznámé $x$ a $y-\mathrm{v}$ tom př́padě by špatné výsledky svědčily opět o problémech se substitucí či s chápáním, že dvojice čísel musí vyhovovat oběma rovnicím, nikoli jen první z nich.

Úlohou, ve které naši žáci zaostali nejvíce, je úloha s neznámou ve jmenovateli (M08-09 - úspěšnost 16,1\%; -8,4\%).

Opět můžeme upozornit na výsledky učitelského dotazníku. Podle učitelů testovaných žáků se $\mathrm{s}$,jednoduchými lineárními rovnicemi a nerovnicemi a soustavami rovnic o dvou proměnných" setkalo jen 53 \% testovaných žáků. Program Základní škola zařazuje lineární rovnice včetně úprav ${ }^{21}$ do 8. ročníku,

${ }_{21}$ Testování proběhlo od března do května 2007, je tedy možné, že někteř́ žáci neměli látku probránu, i když byla plánována na 8. ročník. 
ovšem nerovnice a soustavy rovnic jsou až o rok později. (Z dotazníku nelze zjistit, zda žáci měli rovnice probrány, nebo ne, protože otázka v učitelském dotazníku spojila tento pojem s nerovnicemi a soustavami rovnic, které se však u nás zpravidla neprobírají současně.) Rovnice $s$ neznámou ve jmenovateli byly v programu Základní škola též plánovány až do 9. ročníku.

\subsection{Výrazy}

Poněkud překvapivě dosáhli naši žáci v této oblasti v průměru standardních výsledků (tedy průměrné úspěšnosti o 9,4 \% vyšší, než byl mezinárodní průměr). Nadstandardních výsledků dosáhli naši žáci v pěti úlohách, které tvoří dvě odlišné skupiny.

$\mathrm{V}$ jedné skupině úloh jde o úpravy mnohočlenů sčítáním a násobením (M02-06, M05-02, M06-05). Úspěšnost našich žáků v těchto úlohách je mezi $69 \%$ a $76 \%$, odchylka od mezinárodního průměru od $+15,8 \%$ do $+24,2 \%$.

Druhá skupina zahrnuje úlohy, v nichž mají žáci vybrat výraz, který vyjadřuje jednoduché vztahy ve slovně popsané reálné situaci (M07-06, M11-05). Mezi těmito dvěma úlohami nacházíme na první pohled překvapivý rozdíl v úspěšnosti. První z nich (který výraz odpovídá tomu, že Halina má o 3 bundy více než Anna, když n je počet bund Haliny) řeší správně pouze 55,8 \% žáků (+15\%), zatímco druhou (výraz pro celkový počet balónků, když každý z m chlapců a n dívek má dva balónky) 86,1 \% (+15,2%). Rozdíl ovšem odpovídá zhruba tomu, kolik žáků se v první úloze nechává svést výrazem „více“ ke sčítání, a tedy k volbě výrazu $n+3$. Slovo „více“ zde působí jako tzv. antisignál (Hejný \& Kuřina, 2009) - jde o slovo, které významově navádí k inverzní operaci, než je ta, která vede ke správnému řešení. Někteří zahraniční autoři nazývají takové úlohy inconsistent (např. Fuson, Carroll, \& Landis, 1996).

\section{Slabé a velmi slabé úlohy}

Na úroveň mezinárodního průměru nebo i pod něj klesají výsledky našich žáků v pěti úlohách. Opět tu lze najít dvě výše vyčleněné skupiny, objevuje se ovšem ještě další skupina, kterou by snad bylo možno považovat za náročnější variantu úloh, v nichž si žáci mají uvědomit korespondenci mezi výrazy a vztahy v realitě.

Nejvyšší úroveň obtížnosti úpravy mnohočlenu v testech TIMSS představuje uzavřená úloha M04-07 (úspěšnost 24,7 \%; -1,1\%). Vyžaduje jednak 
roznásobení dvojčlenu, jednak odečtení dalšího dvojčlenu, při němž se „mění znaménko v závorce“: $2(x+y)-(2 x-y)$. Nečastější nesprávné odpovědi odpovídají tomu, že žák nezměnil znaménko u některého členu druhého dvojčlenu.

Vyjádření situace výrazem odpovídá uzavřená úloha M10-08 - jde o vyjádření obsahu obdélníka, který má strany označeny $x$ a $x+2$; úspěšnost řešení klesá na 35,5 \% (-2,8 \%). Nejčastější nesprávná odpověd' $x^{2}+2$ (36,1\%) odpovídá nesprávně provedenému roznásobení závorky - žáci nechápou výraz v závorce jako jeden celek. Můžeme vyslovit domněnku, že úloha by zřejmě měla vyšší úspěšnost, pokud by jako strany obdélníka byla použita „standardní" písmena $a, b$.

Částečně podobná je úloha M09-04 (úspěšnost 42,5\%; +1,5 \%), která však klade otázku obráceně: Co by mohlo být znázorněním výrazu $2 x+3 x$ ? Žáci vybírají ze čtyř situací obsahujících geometrický nákres (obr. 2).

(A) Délka této úsečky:

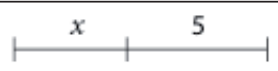

B) Délka této úsečky:

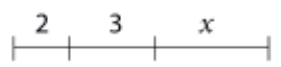

(C) Obsah tohoto obrazce:

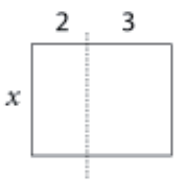

(D) Obsah tohoto obrazce:

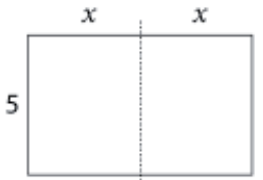

Obrázek 2. Obrázek k úloze M09-04 (Tomášek et al., 2009). 
Žáci nejčastěji vybrali jako nesprávné řešení délku úsečky $A$ a $B$, jako by pod výrazem $2 x$ nebyli schopni vidět obsah (pro jehož vyjádření očekávají druhou mocninu), ale jen délku. K tomu zřejmě přispívá fakt, že jeden rozměr obdélníku je dán číslem, zatímco druhý je označen proměnnou.

V obou úlohách zjevně přispívá k obtížnosti to, že se v nich kombinují - byt' velmi elementárně - výrazy s oblastí Obrazce a tělesa.

Úloha M11-04 zní: Co znamená výraz xy + 1?, přičemž jsou nabídnuty čtyři možnosti čtení výrazu (úspěšnost 64,7 \%; +2,6 \%). Nejčastější nesprávná odpověd' $(20,8 \%)$ odpovídá tomu, že žáci interpretují výraz xy jako součet a ne součin.

Úlohu M11-04 spolu s úlohou M14-05 (úloha typu který výraz odpovídá jedné devítině z $a$ ? - úspěšnost 40,6\%; -5,1\%) bychom mohli vzít jako specifické př́pady otázky, jak číst daný algebraický výraz, resp. která konfigurace reálných vztahů výrazu odpovídá. Zároveň jsou to symptomatické úlohy pro přechod od jazykového vyjádření $\mathrm{k}$ algebraickému zápisu, který je pro české žáky kritickým momentem. To je velmi dobře patrné z některých úloh z oblasti Posloupnosti.

\section{Posloupnosti jako kritické místo}

Do této oblasti jsme zařadili celkem 17 úloh, všechny jsou otevřené. Pouze dvě $\mathrm{z}$ nich však stojí samostatně a obě se týkají číselných řad. $V$ neuvolněné úloze M08-07 jde o Fibonacciho posloupnost a o doplnění číselné řady $(57,5 \%$; +18,5\%). Úloha M07-04 vyžaduje pravidlo, podle kterého je číselná řada sestrojena $(80,5 \% ;+17,5 \%)$. V obou těchto úlohách jsou výsledky českých žáků výrazně nad mezinárodním průměrem.

Všechny ostatní úlohy využívají k vytvoření posloupnosti skládání grafických (geometrických) prvků do stále složitějších (nebo přinejmenším větších) útvarů a kladou u nich otázky na třech úrovních: většinou první z trojice úloh vyžaduje doplnění počtu prvků, které vzniknou v nejbližších dalších členech posloupnosti; druhá úloha požaduje vyjádření (vypočítání) počtu prvků v konkrétních vzdálených členech posloupnosti; třetí úloha pak vyžaduje obecné vyjádření počtu prvků pro $n$-tý člen posloupnosti. Př́íkladem je úloha M02-07 (viz obr. 3). 
Jarda zkoumal vlastnosti mnohoúhelníků. Vypracoval tabulku, aby zjistil, zda je možné najít vztah mezi stranami a úhly.

A. Doplň prázdná políčka v tabulce.

\begin{tabular}{|c|c|c|c|}
\hline Mnohoúhelnik & Počet stran & Počet trojúhelnikủ & $\begin{array}{c}\text { Součet velikostí } \\
\text { vniťrnich úhlü }\end{array}$ \\
\hline & 3 & 1 & $1 \cdot 180^{\circ}$ \\
\hline & - & - & $-180^{\circ}$ \\
\hline & - & - & $-180^{\circ}$ \\
\hline & & & \\
\hline & & & \\
\hline
\end{tabular}

B. Do čtverečku napiš správné číslo.

Součet velikostí vnitřních úhlů mnohoúhelníku s 10 stranami $=\square \cdot 180^{\circ}$

C. Jarda vztah objevil a pomocí $n$ dokázal napsat vzorec, který je pravdivý pro jakýkoliv mnohoúhelník. Doplň, co napsal.

Součet velikostí vnitřních úhlů mnohoúhelníku s $n$ stranami = $\cdot 180^{\circ}$

Obrázek 3. Obrázek k úloze M02-07 (Tomášek et al., 2009).

Výsledky úspěšnosti pro úlohy oblasti Posloupnosti ukazuje tabulka 4 (údaje jsou v procentech, tučně vyznačené rozdíly oproti mezinárodnímu souboru v závorce znamenají slabé a velmi slabé úlohy). 


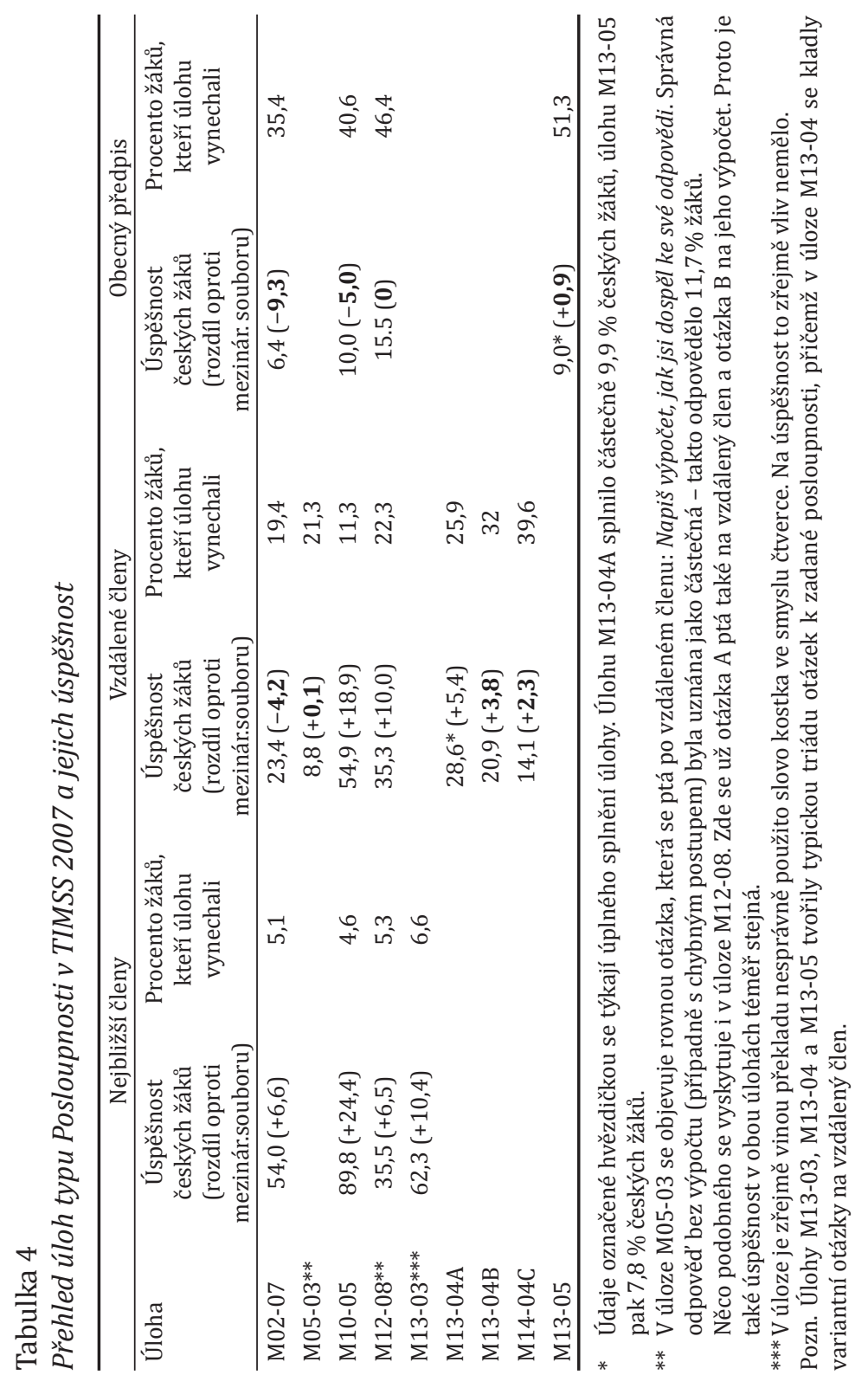


Necháme-li stranou odlišnou obtížnost jednotlivých trojic (až pětic) úloh, která je z tabulky též patrná, je zřetelně viditelné právě to, že výkony českých žáků se zhoršují na dvou kritických místech: na přechodu od názorné představivosti k pochopení závislosti, ale zejména na přechodu od pochopení funkční závislosti (díky němuž dokážou žáci pracovat s konkrétními čísly) k jejímu algebraickému vyjádření. (Nabízí se otázka, zda by naši žáci byli schopni pravidlo formulovat alespoň slovně - jedná se o důležitý předstupeň algebraického vyjádření). Je to vidět z toho, že se výsledky českých žáků blíží mezinárodnímu průměru a dostávají se pod něj, a také z toho, že se významně zvyšuje procento žáků, kteří se o řešení úlohy ani nepokoušejí.

Úlohy na zobecňování představují jednu z cest $\mathrm{k}$ algebře jako zobecněné aritmetice (např. Radford, 2011). Naši žáci však s nimi nemají př́liš zkušeností (na rozdíl např. od žáků z anglosaských zemí). V programu Základní škola není problematika úloh na zobecňování a číselné posloupnosti vůbec zmíněna a ani v analyzované řadě učebnic nejsou úlohy tohoto typu uvedeny. Podle učitelského dotazníku se s „číselnými, algebraickými a geometrickými schématy nebo posloupnostmi (rozvíjení, chybějící členy, zobecňování)“ setkalo jen $64 \%$ testovaných žáků.

Porovnáme-li úlohy v oblastech Posloupnosti a Výrazy, je patrné, že otázku po vyjádření obecného předpisu posloupnosti můžeme též chápat jako otázku po vyjádření vztahů v reálné situaci. $V$ tomto smyslu by se tyto úlohy daly začlenit do Výrazů. Je tu patrný výrazný rozdíl v úspěšnosti řešení, který zřejmě souvisí is tím, že v úlohách zahrnutých do Výrazů jde o úlohy s výběrem odpovědi, zatímco v Posloupnostech jde o odpovědi otevřené. Zatímco dvě nejobtížnější uzavřenéúlohy ve Výrazech, vyžadující vyjádření vztahů v reálné situaci (M10-08 a M09-04), mají úspěšnost 35,5 \%, resp. 42,5 \%, v úlohách $\mathrm{s}$ otevřenou odpovědí v oblasti Posloupností se úspěšnost pohybuje pouze mezi $6,4 \%$ a $12,9 \%$. Dalo by se tedy uvažovat o tom, že kolem $40 \%$ českých žáků dokáže rozpoznat správný výraz v nabídnutých odpovědích (nebo ho uhodnout), avšak mají-li ho sami zkonstruovat, úspěšnost dramaticky klesá. Totéž ovšem platí ve většině úloh i u mezinárodního souboru, jen v některých úlohách je u našich žáků pokles ještě výraznější.

\section{Obrazce a tělesa jako kritické místo}

Jde o oblast v TIMSS rozsáhle zastoupenou. Zahrnuli jsme do ní 21 úloh, které jsme většinou vyčlenili z kognitivní domény TIMSS Geometrie. Řadíme 
sem takové úlohy, které nevyžadují jen základní znalosti o vlastnostech geometrických útvarů (jako je napřs součet úhlů v trojúhelníku či vlastnosti souhlasných, střídavých a vrcholových úhlů), ale také jejich využití v složitějších úlohách. Jde většinou o úlohy „na obsah, obvod, povrch, objem a Pythagorovu větu“. (Rozlišení mezi touto oblastí a oblastí Geometrie pochopitelně není zcela ostré.)

Vysoko nad mezinárodním průměrem i svým vlastním standardem jsou čeští žáci ve dvou úlohách: M09-09 (Kolik krychlí by bylo zapotřebí k zaplnění otvoru?, přičemž je nakresleno těleso s otvorem tvaru kvádru sestavené z krychlí - úspěšnost 67,4 \%; +25,1\%), M14-11 (kolik krychliček zůstalo $v$ krychli, když se některé (zadáním přesně určené) krychličky odeberou úspěšnost $68,1 \% ;+24,7 \%$ ).

Jen o něco níže skórují naši žáci v úloze M04-11, v níž se má nakreslit ve čtverečkovaném papíru trojúhelník s obsahem dvakrát větším, než je obsah zadaného obdélníku (úspěšnost 64,7 \%; +15,9\%). Dá se uvažovat o tom, že společným rysem úloh je představivost $\mathrm{v} 2 \mathrm{D}$ i 3D prostoru strukturovaném čtverečky (resp. krychličkami), přičemž tato strukturace je vizuálně znázorněna. $V$ úloze M13-0322, kde si žáci musí takovou strukturaci pouze představit (pokud si ji sami nenakreslí), resp. ji musejí extrapolovat z obrazců o menších rozměrech, se odstup od mezinárodního prủměru snižuje na standardních 10,4 \% (úspěšnost 62,3 \%), přesto jde tedy o slušný výsledek.

\section{Slabé a velmi slabé úlohy}

Kolem úrovně mezinárodního průměru, kolem $9 \%$ pod svým standardem, se pohybují výkony našich žáků $\mathrm{v}$ devíti úlohách. Lze říci, že zřetelným společným rysem těchto úloh je nutnost použít znalost vzorce (pro obsah, objem) jako vztahu parametrů obrazce či tělesa ve vícekrokovém řešení.

Otevřenou úlohu M01-11A (obr. 4) řešilo úplně 19,8 \% žáků (+3,4 \%), částečně pak dalších $14,2 \%$. Velká část žáků $(20,7 \%)$ úlohu vynechala.

22 Tuto úlohu zařazujeme i do oblasti Posloupnosti (viz výše). 


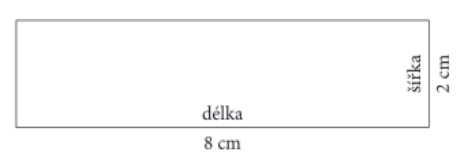

Do čtvercové sítě dole nakresli obdélník, jehož délka se rovná třem čtvrtinám délky obdélníku na horním obrázku a jehož šiŕrka se rovná dva a půl násobku šířky obdélníku na horním obrázku. Ve svém obrázku uved' délku a šíŕku nakresleného obdélníku v centimetrech. Strana čtverce ve čtvercové síti je dlouhá $1 \mathrm{~cm}$.

Obrázek 4. Zadání úlohy M01-11A (Tomášek et al., 2009).

Naprostá většina částečných odpovědí spočívala $\mathrm{v}$ tom, že obdélník byl správně nakreslen, ale délka a/nebo šiŕka nebyla uvedena, príípadně byla uvedena chybně. Je patrné, že obtížný moment této úlohy souvisí s výpočtem stran, a tedy nikoli primárně s oblastí Obrazce a tělesa. Problém výpočtu byl zřejmě ve slovním vyjádření násobků a také v tom, že nešlo o násobky celočíselné. Chybný výpočet jedné ze stran se objevil v pětině všech pokusů o řešení.

Následnou úlohu M01-11B (Jaký je poměr obsahu původního obdélníku kobsahu nového obdélníku?) vynechalo 49,9 \% žáků. Frekvence úplných řešení byla 10,4 \% (-0,6 \%). Většina žáků, kteří uvedli částečné odpovědi $(3,3 \%)$, chybovala v tom, že uvedla obrácený poměr. Hodnocení správnosti odpovědi bylo téměř nezávislé na správnosti řešení předchozí úlohy, za správnou odpověd' byl uznán každý odpovídající poměr obsahů, vycházejících z délek stran, $\mathrm{k}$ nimž respondent dospěl $\mathrm{v}$ předchozí úloze. Je tedy možné, že úlohu správně řešili i někteří $\mathrm{z}$ těch, kteří v předchozí úloze dospěli $\mathrm{k}$ chybným délkám obou stran, tím spíše pak ti, kteří měli nesprávný výpočet pouze jedné strany. Bohužel kromě částečně správných řešení známe povahu chyb pouze u necelých dvou procent žáků, kteří se zaměřili výhradně na poměry délek a/nebo širřek mezi obdélníky nebo $\mathrm{v}$ obdélnících. 0 povaze naprosté většiny chybných řešení (25,9 \% žáků) nemáme údaje a nevíme tedy, nakolik měli žáci problém s výpočtem obsahu a nakolik se sestavením poměru.

Je třeba si povšimnout, že se nedá považovat za samožrejmé, že pokud v úloze A žáci dospěli k nějakým délkám stran, pak správně zjistili i obsah obdél- 
níka. Ve skutečnosti museli v úloze B udělat několik kroků navíc: vypočítat obsahy (to $\mathrm{v}$ úloze $\mathrm{A}$ nemuseli), dát je do poměru a možná ještě správně poměr vykrátit. Poslední krok nebyl nezbytně nutný, pokud by uvedli jako odpověd' jen špatně vykrácený poměr - bez původního správného, který krácení předcházel, byla by odpověd' brána jako nesprávná.

Úloha M05-04 je na obr. 5 (29,8 \%; +0,9 \%; třetina našich žáků úlohu vynechala).

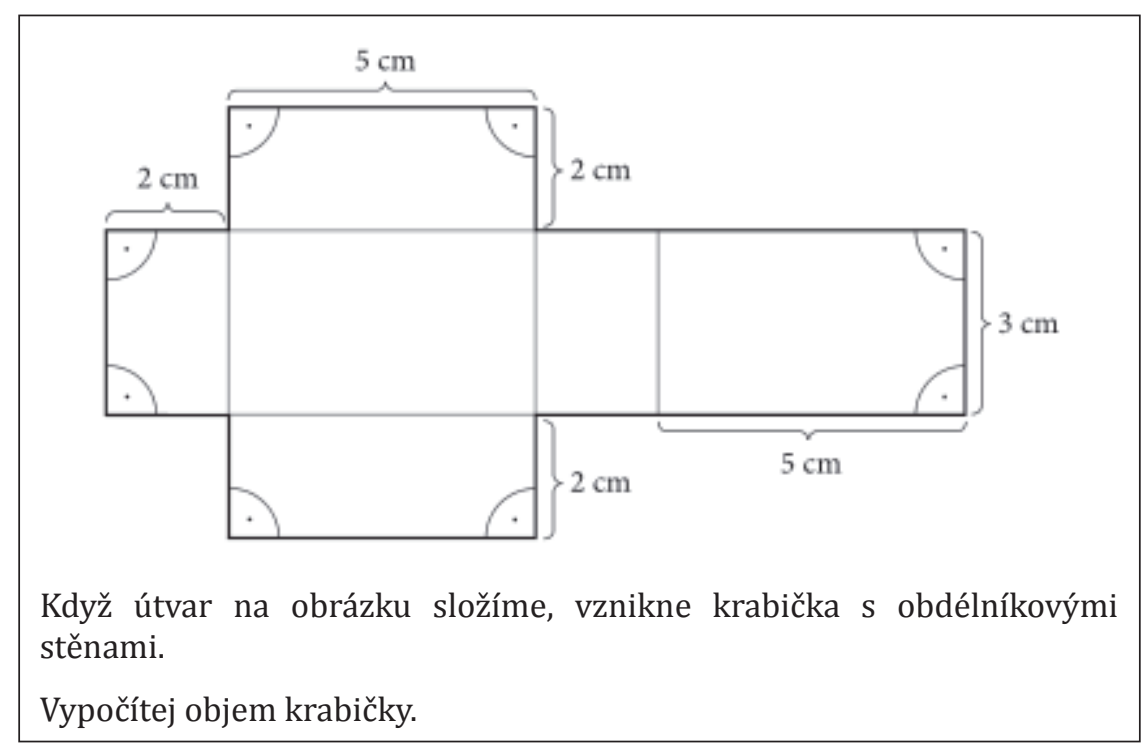

Obrázek 5. Zadání úlohy M05-04 (Tomášek et al., 2009).

Problém je, že nevíme, co způsobilo špatnou úspěšnost úlohy. Nedovedli si žáci na základě sítě představit výsledný kvádr? Nebyli schopni na základě sítě identifikovat rozměry kvádru? Nebo byl problém až ve fázi výpočtu objemu, a tedy ve vzorci? Přesto však př́ŕčinu neúspěchu můžeme spatřovat mj. v tom, že ve výuce na našich školách se vyskytuje málo úloh, v nichž se má usuzovat na vlastnosti tělesa na základě jeho sítě. $V$ analyzované řadě učebnic žádné podobné úlohy nejsou. Podle učitelských dotazníků se s problematikou 
„Vztahů mezi 2D a 3D útvary“, kam můžeme tuto úlohu zařadit, setkalo jen $48 \%$ testovaných žáků.

Za tradiční můžeme považovat úlohu M07-07: Kruhový rybník má poloměr 10 metrů. $V$ průměru pripadají na jeden čtverečný metr v rybníku 2 žáby. Přibližně kolik žab je v rybníku? $\pi$ je přibližně 3,14. (úspěšnost 31,9\%; +3,5 \%). Jedná se o vícekrokovou úlohu, v níž bylo třeba kromě obsahu kruhu použít př́mé úměrnosti a vhodně zaokrouhlit. Nejčastější chybná odpověd' 120 žab $(35,6 \%)$ zřejmě vychází $\mathrm{z}$ výpočtu $2 \pi r \cdot 2$ (případně $\pi d \cdot 2)$ a zaměňuje tedy obsah kruhu za jeho obvod bud' na úrovni pojmů, nebo vzorců. Druhá nejčastější chyba 300 žab (22 \%) považuje správně vypočítaný přibližný obsah rybníka již za počet žab a opomíná nutný druhý krok řešení.

V uzavřené úloze M09-08 měli žáci vypočítat obvod čtverce, když známe jeho obsah $144 \mathrm{~cm}^{2}$ (úspěšnost $43 \% ;+0,3 \%$ ). Nejvíce špatných odpovědí $(27,1 \%$ ) odpovídalo tomu, že žáci provedli jen první krok řešení, tedy odmocnili číslo 144. Velká část žáků (18,3 \%) zvolila odpověd’ 288 cm. Je možné, že žáci místo odmocnění čísla 144 vydělili číslo 144 dvěma. Tím dostali 72 , což považovali za délku strany, a po vynásobení čtyřmi dostali 288. Někteří žáci mohli být neúspěšní i proto, že si nevybavili druhou odmocninu čísla 144, i když pojem obsahu a obvodu jim jasný byl.

Uzavřená úloha M09-10 (48,1 \%; +0,6 \%) je mezi ostatními atypická (obr. 6). Jedná se vlastně o „obrácenou Pythagorovu větu“ (pokud pro délky stran trojúhelníka platí určitá rovnost, pak je trojúhelník pravoúhlý). Té se zřejmě ve školách nevěnuje tolik pozornosti jako Pythagorově větě jakožto implikaci pokud je trojúhelník pravoúhlý, pak pro délky jeho stran platí určitá rovnost. Všechny nesprávné odpovědi (nejčastější je B, a sice 20,6 \% žáků) lze interpretovat jako snahu o využití trojúhelníkové nerovnosti, což je poznatek, který je žákům známý již prakticky od prvního stupně základní školy.

Další tři úlohy, u nichž se naši žáci pohybovali pod svým standardem, se týkají hledání obsahu útvaru vepsaného do jiného útvaru. První z nich je úloha M11-07 na obrázku 7 (32,8 \%; -1\%). ${ }^{23}$

${ }_{23}$ Úloha není zcela korektně zadaná, nebot' není řečeno ani v obrázku vyznačeno, že se jedná o obdélník. To však zřejmě problémy žákům nepůsobilo. Předpokládali, že tomu tak je. 


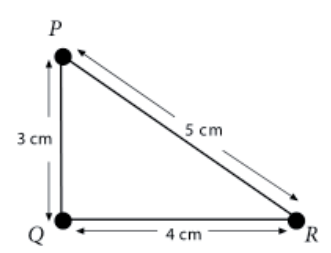

Ze kterého zápisu vyplývá, že trojúhelník $P Q R$ je pravoúhlý?

A) $3^{2}+4^{2}=5^{2}$, B) $5<3+4$, C) $3+4=12-5$, D) $3>5-4$

Obrázek 6. Zadání úlohy M09-10 (Tomášek et al., 2009).

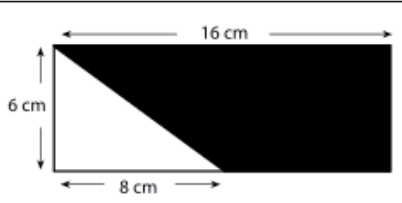

Kolik $\mathrm{cm}^{2}$ je obsah tmavé části obrazce na obrázku?

A) $24 \mathrm{~cm}^{2}$, B) $44 \mathrm{~cm}^{2}$, C) $48 \mathrm{~cm}^{2}$, D) $72 \mathrm{~cm}^{2}$

Obrázek 7. Zadání úlohy M11-07 (Tomášek et al., 2009).

K úloze můžeme přistoupit několika způsoby. Bud’ standardním postupem pomocí vzorce pro obsah lichoběžníku (problémem pak je, že si žáci často vzorec nepamatují), nebo úvahou. Ta může spočívat napřv v tom, že vypočítáme obsah bílého trojúhelníka a odečteme ho od obsahu celého obdélníku ovšem pokud je v úloze přítomna myšlenka výpočtu pomocí komplementu, je zpravidla pro žáky obtížnější. Navíc černý útvar na sebe poutá příliš velkou pozornost. Další způsob spočívá v tom, že si černý lichoběžník rozdělíme na obdélník a trojúhelník. To je ovšem pro naše žáky obtížné - podobné úlohy se v učebnicích objevují jen zřídka. Navíc je obtížné vyznačit v černě vybarveném obrázku úsečku oddělující obdélník a trojúhelník, rozdělení je tedy nutně jen pomyslné. 
Nejpočetnější nesprávná odpověd’ C (23,2 \%) by mohla znamenat, že žáci prostě vynásobili rozměry odvěsen bílého trojúhelníka, nebo počítali obsah lichoběžníku pomocí vzorce pro obsah trojúhelníku $(16 \cdot 6 / 2)$. Odpověd' B (16,6 \%) odpovídá obvodu obdélníka a odpověd' A (20,4 \%) odpovídá obsahu bílého trojúhelníku. U odpovědi A by se mohlo jednat o první krok strategie komplementu, ovšem s jistotou se to tvrdit nedá. Možná v tomto př́padě (a podobně i v případě jiných uzavřených úloh) může jít o strategii použiji jako odpověd' první č́slo, ke kterému dospěji a které se přitom objevuje $v$ nabídce.

V uzavřené úloze M14-12 (která patří mezi neuvolněné) měli žáci vypočítat obsah trojúhelníka složeného ze dvou menších pravoúhlých trojúhelníků, předtím však bylo nutno pomocí Pythagorovy věty vypočítat délku jedné ze stran $(23 \% ;-3,3 \%)$.

Výrazněji pod mezinárodním průměrem jsou pak výsledky našich žáků v úloze M01-12 (obr. 8; 23,1 \%; -5,6 \%; 16,3 \% žáků úlohu vynechalo).

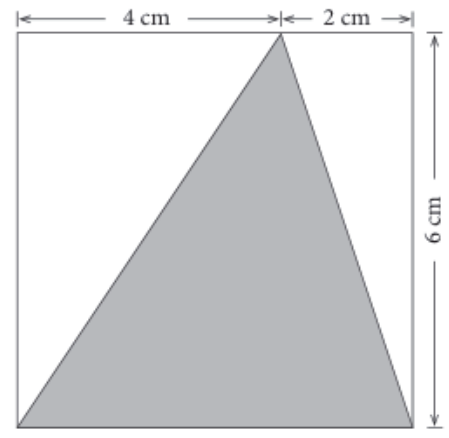

Na obrázku je uvnitř čtverce vybarvený trojúhelník. Jaký je obsah vybarveného trojúhelníku?

Obrázek 8. Zadání úlohy M01-12 (Tomášek et al., 2009).

Domníváme se, že existují přinejmenším tř̌i možnosti, jak úlohu řešit (viz také úloha na obr. 7): 
1) Pomocí vzorce pro obsah trojúhelníku - je nutno si uvědomit, že výška trojúhelníku je stejně velká jako strana čtverce.

2) Pomocí rozdělení čtverce na dílčí konfigurace - na dva obdélníky dokreslením nebo domyšlením si kolmice jdoucí vrcholem trojúhelníku; je nutno si uvědomit, že pak strany trojúhelníku jsou úhlopříčky těchto obdélníků a že tedy v nich vyšrafovaná část zabírá právě jednu jejich polovinu. Obsah vyšrafované části je tedy polovinou obsahu čtverce.

3) Pomocí posunutí vrcholu trojúhelníku např. do pravého horního vrcholu čtverce - obsah trojúhelníku se nezmění, protože se nezmění ani strana ani výška, a je vidět na první pohled, že hledaný obsah je polovinou obsahu čtverce. Tento dynamický pohled na situaci je nejobtížnější.

Tedy důvodem nízké úspěšnosti našich žáků u této úlohy může být kromě neznalosti vzorce pro obsah trojúhelníka či neschopnosti nalézt v obrázku výšku (jak uvádí Tomášek et al., 2009) také neschopnost si obrázek rozdělit na části, jejichž obsah se lehce zjistí.

U úloh podobných těm na obr. 7 a 8 hovoří F. Kuřina o umění vidět v geometrii (Kuřina, 2006) a dlouhodobě upozorňuje na fakt, že se této problematice ve školské geometrii věnuje jen málo pozornosti na úkor procvičování používání vzorců. Tyto úlohy mohou sloužit jako diagnostické pro zjištění, kteří žáci disponují dobrým geometrickým viděním a schopností odvodit jiný postup, pokud nemají pohotově $\mathrm{k}$ dispozici vzorec nebo mu pro něj chybí některé parametry. ${ }^{24}$

\section{Závěr}

V tomto článku jsme identifikovali některá obtížná místa učiva na 2. stupni základní školy prostřednictvím sekundární analýzy výsledků českých žáků při řešení úloh TIMSS 2007. Domníváme se, že analýza jednotlivých úloh a snaha pochopit, v čem jsou jejich jednak specifické, jednak společné obtížné momenty, nás dovedla ke zjištěním, která přinejmenším svou konkrétností přesahují to, co se dozvídáme z běžných analýz celkových ukazatelů, jak jsou prezentovány v mezinárodních a národních zprávách i dalších publikacích.

${ }_{24}$ Úlohu jsme zadali žákům 7. a 8. ročníků a ukazuje se, že významné procento z nich používá nesprávné vzorce pro obsah trojúhelníka. Ukazuje to na př́lišné lpění na vzorcích i tam, kde nejsou nutné. Strategie řešení žáků však ještě nemáme zcela analyzované a budou předmětem zvláštního článku. 
Z naší analýzy je patrné, že obtížná místa se u našich žáků koncentrují především do dvou širších okruhů. Jedním z nich jsou různé aspekty algebry, jak ji koncipují úlohy TIMSS, druhou pak úlohy vyžadující využití znalostí o vlastnostech geometrických útvarů ve složitějších výpočtech.

V algebře je možno poukázat na některé dílčí momenty, které našim žákům působípotíže, jako je práce se zápornými čísly a zlomky ve výrazech a rovnicích, neznámá ve jmenovateli, substituce ve složitějších výrazech, dosazování hodnot z uspořádaných dvojic nebo systematické testování platnosti rovnice vícenásobným dosazováním za proměnné. Jak jsme doložili výše, v některých př́padech se může jednat o to, že se dané problematice obecně nevěnuje ve výuce pozornost (např. dosazování výrazů s proměnnými) či je zařazena ve vyšším ročníku. Domníváme se ovšem, že za těmito jednotlivostmi stojí obecnější problémy, které se v TIMSS také projevily.

Ukazuje se, že slabinou našich žáků je nedostatečná schopnost postihnout pravidelnosti $\mathrm{v}$ řadě graficky nebo číselně prezentovaných kvantit, ale především pak schopnost jejich zobecnění, a to zejména prostřednictvím algebraického zápisu. To souvisí s chápáním konceptu funkce ne-li v celé jeho šírí, pak alespoň v různosti jeho projevů - jako závislosti dvou proměnných (veličin, řad), jako rovnice o dvou neznámých s nekonečným počtem řešení, která mohou být vyjádřena jako uspořádané dvojice, jež při zobrazení funkce grafem hrají roli souřadnic, jimiž graf prochází, apod. Zatímco s reprezentacemi funkcí se žáci, doufejme, seznamují na střední škole, problematice zobecňování se obecně nevěnuje dostatečná pozornost.

Další slabinu v algebře lze vyjádřit jako přechody od popisu situace $\mathrm{k}$ algebraickému zápisu (výrazu, rovnici) a opačně, chápání korespondence proměnných a operací s nimi. Naši žáci zvládají poměrně dobře úpravu výrazů a také jednoduché případy korespondence mezi výrazem a explicitně popsanou či zobrazenou situací. Nezvládají však složitější př́ípady, jaké v TIMSS 2007 představují např. Posloupnosti nebo úlohy, v nichž se má identifikovat a vyjádřit funkční závislost dvou řad údajů, jak jsme zmiňovali výše.

Na druhou stranu se domníváme, že úlohy TIMSS 2007 nepostihují ještě další přechody, které předcházejí algebraickému zápisu: od intuitivního pochopení funkční závislosti k jejímu explicitnímu slovnímu vyjádření a od tohoto vyjádření $\mathrm{k}$ algebraickému zápisu. 
Ukazuje se zřetelně, že algebra je v úlohách TIMSS pojata v mnohem širších souvislostech, než je běžné na našich základních školách a v učebnicích pro základní školu. Když je v našich výzkumných rozhovorech s učiteli zmíněna algebra jako možné obtížné místo, mluví učitelé víceméně jen o úpravě výrazů, př́padně o řešení rovnic. Př́padné ostatní aspekty pak zahrnují do málo diferencovaného „balíku“ slovních úloh, se kterými „je vždycky problém“.

V úlohách, které jsme zahrnuli do oblasti Obrazce a tělesa a které vlastně stojí na pomezí mezi algebrou a geometrií, se objevují slabiny, které se mohou jevit jako specifické dílčí fenomény: vyvození vlastností tělesa z jeho sítě, pomyslné rozčlenění složitějšího obrazce na jednodušší („umění vidět“), chyby nebo záměny ve vzorcích pro výpočty obvodu, obsahu, objemu a povrchu, potíže s identifikací podmínek pro použití Pythagorovy věty. Domníváme se však, že se tu do značné míry opakují tytéž problémy jako v algebře. Zobrazenou či popisovanou realitu či situaci zde ovšem představuje realita či situace geometrická. Např. záměny vzorců pro obvod, obsah, objem a povrch nejsou problémem pouhého zapamatování. Je třeba je vidět také jako problém vztažení algebraického výrazu či rovnice ke geometrické situaci. Tato korespondence se však pro žáky značně komplikuje, pokud jimi geometrické útvary nejsou viděny ve svých geometrických kvalitách, pokud jimi nejsou spontánně strukturovány jako soubory geometrických elementů, parametrů, vlastností, vztahů. Pak mají žáci logicky problémy, k čemu rovnici, výraz a v nich obsažené proměnné vztáhnout. Ale úloha může přesahovat jejich aktuální dispozice i tehdy, pokud geometrická strukturace je sama o sobě úkolem, který výrazně zatěžuje kapacitu jejich pracovní paměti.

Kromě specifických problémů každé oblasti se objevují některé obecné momenty. $\mathrm{V}$ řadě úloh se zdá, že chybující žáci nejsou schopni pracovat s dvěma předpoklady či podmínkami zároveň a spokojují se s řešením, které vyhovuje pouze jedné (nejčastěji první) z nich. Podobně postupují v úlohách, které vyžadují více kroků; jako by se spokojili s prvním a další už nebrali v úvahu. Tyto chyby v naprosté většině nekorespondují s délkou textu zadání a nespočívají tedy $\mathrm{v}$ tom, že by se řešitel $\mathrm{v}$ něm ztrácel. Problémy tu jsou dány složitostí (či složeností) úlohy, nikoli textu samotného.

Z našich dřívějších výzkumů je zřejmé, že žáci často při řešení složitějších úloh nepostupují tak, že by si nejdříve vypracovali vhled do úlohy a stanovili postup výpočtu (posloupnost jednotlivých kroků). Postupují částečným zkusmým výpočtem, po němž se znovu pokusí o pochopení „jak dál“. Mají-li 
však nabídku odpovědí, která zahrnuje číslo, ke kterému zkusmým výpočtem došli, často už dále nepokračují - právě proto, že na začátku nedisponovali celou strategií výpočtu. ${ }^{25}$ To ukazuje na jednu ze slabin uzavřených úloh s nabídkou odpovědi - žáci mohou hádat, ale mohou také vybrat ten výsledek, k němuž ve vícekrokovém řešení dospějí v prvním kroku.

Ačkoli jsme se snažili postupovat $\mathrm{v}$ analýze úloh a žákovských odpovědí co nejpečlivěji a vytěžit z ní maximum, narazili jsme na to, že data, která máme z TIMSS 2007 k dispozici, trpí přinejmenším dvojím omezením. Prvním je nejednoznačnost interpretací postupů, které stojí za jednotlivými odpověd'mi. Tatáž odpověd' může někdy znamenat různé úvahy a postupy. Přestože jsme využívali svých zkušeností se žákovskými strategiemi a způsoby uvažování z předchozích výzkumů, přece jen jsme občas zůstávali na pochybách nebo jsme na interpretaci rezignovali.

Druhým omezením je to, že především uzavřené úlohy limitují druhy chyb, které žáci mohou udělat. Může se tak stát, že za typickou chybu budeme považovat něco, co by se při jiné nabídce odpovědí nebo při její absenci vyskytlo mnohem méně nebo dokonce vůbec. V některých úlohách bychom tak autorům testu mohli vytknout, že žákưm nenabídli i jiné možnosti a nechali jim tak možnost chybovat jen ,jedním směrem“.

Nicméně takovým omezením se žádné šetření tohoto typu nemůže vyhnout. Je třeba proto jeho zjištění nepřeceňovat a nespokojovat se s nimi. Důkladný vhled do žákovských strategií a logiky jejich úvah mohou poskytnout jen výzkumy založené na kvalitativní metodologii, kde data získáváme v osobním kontaktu s žáky-řešiteli a v komunikaci s nimi. Právě tomu se v současné době věnujeme v rámci projektu GA ČR. Ze slabých a velmi slabých úloh vybíráme takové, u nichž mohl mít neúspěch našich žáků více různorodých př́ičin (např̀ výše zmíněné úlohy M05-10, M06-08, M08-08, M06-10, M04-07, M0904, M11-04, M01-11B), př́padně úlohy jim podobné, a pomocí klinických rozhovorů se žáky druhého stupně základní školy získáváme hlubší vhled do problematiky. Tento hlubší vhled bude tématem dalších článků.

25 To neznamená, že strategie „zkusím a uvidím“ je vždy zavrženíhodná. Naopak skutečně bývá cestou ke konečnému porozumění úloze. To dokonce může přijít až ex post - pokud si ovšem žák zpětně ozřejmí, co a jak v jednotlivých krocích vlastně dělal. 


\section{Literatura}

Basl, J. (2009). Širší souvislosti mezinárodního srovnání výsledků českých žáků v matematice a přírodních vědách. Socioweb, č. 6. Dostupné z http://www.socioweb.cz/index.php?disp =teorie\&shw $=407 \& \mathrm{lst}=108$

Basl, J., \& Mouralová, M. (2011). Zhoršující se výsledky českých žáků v mezinárodních šetřeních: přehled trendů, možné prŕčiny a řešení. Praha. Dostupné z http://www.verejna-politika.cz/ index.php?option=com_content\&view=article\&id=80\&Itemid $=91$

Caponera, E., \& Russo, P. M. (2010). Performance in TIMSS mathematics test: The influence of self-concept and socio-economic background. Cadmo, 18(2), 91-103.

Dodeen, H., Abdelfattah, F., Shumrani, S., \& Hilal, M. A. (2012). The effects of teachers' qualifications, practices, and perceptions on student achievement in TIMSS mathematics: A comparison of two countries. International Journal of Testing, 12(1), 61-77.

Fuson, K. C., Carroll , W. M., \& Landis, J. (1996). Levels in conceptualizing and solving addition and subtraction compare word problems. Cognition and Instruction, 14(3), 345-371.

Grulichová, M. (2009). I v matematice platí: bez práce nejsou koláče. Týdeník Školství, 18. Dostupné z http://www.tydenik-skolstvi.cz/archiv-cisel/2009/18/i-v-matematice-platibez-prace-nejsou-kolace/

Hejný, M., \& Kuřina, F. (2009). Dítě, škola, matematika. Konstruktivistické přístupy k vyučování. Praha: Portál.

Hejný, M., et al. (2010). Matematické úlohy pro druhý stupeň základního vzdělávání: Náměty pro rozvoj kompetencí žáků na základě zjištění výzkumu TIMSS 2007. Praha: ÚIV. Dostupné z http://www.uiv.cz/clanek/595/2154

Choi, K., Choi, T., \& McAninch, M. (2012). A comparative investigation of the presence of psychological conditions in high achieving eighth graders from TIMSS 2007 Mathematics. ZDM, 44(2), 189-199.

Janík, T. (2013, září). Mezinárodně srovnávací výzkumy vyučování a učení ve školních třídách a didaktika. Př́spěvek prezentovaný na odborném kolokviu Srovnávací pedagogika: Proměny a výzvy, Praha.

Kuřina, F. (2006). Geometrie jako př́ležitost k rozvoji žákovských kompetencí. In Podíl učitele matematiky Ž̌ na tvorbě ŠVP : Studijní materiály $k$ projektu. Praha: JČMF. CD ROM. Dostupné z http://class.pedf.cuni.cz/NewSUMA/Default.aspx?PorZobr=20\&PolozkaID=$1 \&$ ClanekID $=188$

Louis, R., \& Mistele, J. (2012). The differences in scores and self-efficacy by student gender in mathematics and science. International Journal of Science and Mathematics Education, 10(5), 1163-1190.

Mandíková, D. (2009). Výsledky českých žáků ve výzkumu TIMSS 2007. In Sborník ze semináre OS FPS JČMF: Jak učím fyziku? (s. 13). Ústí nad Labem: PF UJEP.

Mullis, I. V. S., Martin, M. O., Ruddock, G. J., O'Sullivan, C. Y, Arora, A., \& Erbeber, E. (2005). TIMSS 2007 Assessment frameworks. Chestnut Hill: TIMSS \& PIRLS International Study Center, Boston College.

Mullis, I. V. S., Martin, M. O., \& Foy, P., et al. (2008). TIMSS 2007 international mathematics report: Findings from IEA's Trends in International Mathematics and Science Study at the fourth and eight grades. Boston: TIMSS \& PIRLS International Study Center, Lynch School of Education, Boston College. 
Neubrand, M. (2009). Von den „grossen“ Studien zur Umsetzung „im Kleinen“: Welche (mathematik-didaktischen) Impulse können Lehrer/innen aus „PISA \& Co“ ziehen? In T. Bohl \& H. Kipper (Eds.), Lernen aus Evaluationsergebnissen: Verbesserungen planen und implementieren (s. 97-112). Bad Heilbrunn: Klinkhardt.

Palečková, J., Tomášek, V., \& Basl, J. (2010). Hlavní zjištění výzkumu PISA 2009: Umíme ještě číst? Praha: ÚIV.

Potužníková, E., \& Straková, J. (2006). Rozdíly ve vědomostech a dovednostech českých chlapců a děvčat na základě zjištění mezinárodních výzkumů. Sociologický časopis / Czech Sociological Review, 42(4), 701-717.

Rabušicová, M. (2011). Měření výsledků vzdělávání na mezinárodní a národní úrovni. Universitas. Revue Masarykovy univerzity, 44(2), 15-21.

Radford, L. (2011). Grade 2 students' non-symbolic algebraic thinking. In J. Cai \& E. Knuth (Eds.), Early algebraization. Advances in Mathematics Education (s. 303-322). Berlin: SpringerVerlag.

Straková, J. (2009). Vzdělávací politika a mezinárodní výzkumy výsledků vzdělávání v ČR. Orbis scholae, 3(3), 103-118.

Robitaille, D. F., \& Beaton, A. E. (Eds.). (2002). Secondary analysis of TIMSS data. Dordrecht: Kluwer Academic Publishers.

TIMSS 2011 user guide for the international database. Released items. Mathematics - eight grade. Dostupné z www.timss.org

TIMSS 2007 - International database - Almanacs. Dostupné z www.timss.org.

Tomášek, V., et al. (2008). Výzkum TIMSS 2007. Obstojí čeští žáci v mezinárodní konkurenci? Praha: ÚIV.

Tomášek, V., et al. (2009). Výzkum TIMSS 2007 - úlohy z matematiky pro 8. ročník. Praha: ÚIV.

Tomášek, V., \& Mandíková, D. (2009/10). Výsledky českých žáků ve výzkumu TIMSS 2007. Matematika - fyzika - informatika, 19, 275-291.

\section{Autoři}

PhDr. Miroslav Rendl, CSc., Univerzita Karlova v Praze, Pedagogická fakulta, M. D. Rettigové 4, 11639 Praha 1, e-mail: miroslav.rendl@pedf.cuni.cz

doc. RNDr. Nad’a Vondrová, Ph.D., Univerzita Karlova v Praze, Pedagogická fakulta, M. D. Rettigové 4, 11639 Praha 1, e-mail: nada.vondrova@pedf.cuni.cz

\section{Critical areas of mathematics for Czech pupils based on TIMSS 2007 data}

Abstract: The goal of the empirical study is to describe critical areas of primary mathematics as can be found from the Czech Grade 8 pupils' results in TIMSS 2007 and to identify possible causes of their difficulty for pupils. In the first part, a research background is briefly given - international comparative research in mathematics 
and possibilities of the secondary analyses of its data. The second part describes methodology in detail. We analysed data from so called TIMSS almanacs (results of Czech pupils at the level of concrete mathematical items from TIMSS and answers of the teacher questionnaire). To interpret possible causes we also used curricular documents and the analysis of the apparently most used primary mathematics textbooks. We set up a criterion for deciding whether the Czech pupils' results for the given item is below their standard which we determined by comparing their average success rate with that of the international sample. Thus so called weak and very weak items were identified. They were divided into three areas which can be considered critical areas for Czech pupils: Algebra (with subareas of Functions, Substitution, Equations and inequalities, Expressions), Sequences, Shapes and solids. For each of the areas, weak and very weak items are presented together with their results and an outline of the nature of their difficulty for Czech pupils and possible causes of Czech pupils' failure to solve them. It transpires that it is necessary to get a deeper insight into the nature of problems by clinical interviews with pupils. This will be a topic of further articles.

Keywords: TIMSS, mathematical knowledge and skills, algebra, sequences, geometry, difficulties in mathematics

Moon, J. A., Diviš, M., Kolář, J., Dočekal, V., Valenta, J., Kasíková, H., Horká, H., Rodriguezová, V., Brücknerová, K., \& Dubec, M. (2013). Krajinou zkušenostně reflektivního učení. Brno: Masarykova univerzita.

Zkušenostně reflektivní učení je výchovně vzdělávacím konceptem, jenž má v pedagogické historii zapuštěny velmi hluboké a silné kořeny, a již od třicátých let minulého století je spojen s poměrně extenzivním rozvojem napříč mnoha vědními disciplínami. Zcela obecně jej lze vymezit jako takový proces učení, v němž se lidé individuálně nebo ve spolupráci s ostatními pokoušejí prostřednictvím cílené reflexe a ověřování či transformace zažitého objevit nové možnosti, které nemusejí být zřejmé z běžné zkušenosti. Takto nově získaným informací přiřazují osobní význam s individuálním dopadem na jejich bezprostřední životní realitu a jejich fungování v ní. Předkládaná publikace prohlubuje dosavadní poznání tohoto pozoruhodného edukačního konceptu. Neklade si přitom ambici vytvořit přesnou a podrobnou mapu „krajiny“ zkušenostně reflektivního učení. Jejím cílem je spíše zaostřit pozornost na aktuální dění, jež se v této velmi živelné oblasti na několika různých úrovních a v rámci poměrně rozmanitých témat odehrává. 